\title{
Ownership Structure Characteristics and Firm Performance: A Conceptual Study
}

\author{
Ebrahim Mohammed Al-Matari \\ Faculty of Business and Economics, Ammran University, Yemen and Othman Yeop Abdullah \\ Graduate School of Business, University Utara Malaysia, Malaysia \\ Email: ibrahim_matri@yahoo.com \\ Abdullah Kaid Al-Swidi \\ Othman Yeop Abdullah Graduate School of Business, University Utara Malaysia, Malaysia \\ Email: swidi@uum.edu.my \\ Faudziah Hanim Bt Fadzil \\ Othman Yeop Abdullah Graduate School of Business, University Utara Malaysia, Malaysia \\ Email: fhanim@uum.edu.my
}

Doi:10.5296/jsr.v4i2.4835

URL: http://dx.doi.org/10.5296/jsr.v4i2.4835

\begin{abstract}
This study aims to offer a comprehensive description of the relevant literature related to the association between the ownership structures, namely; ownership concentration, managerial ownership, government ownership, foreign ownership and institutional ownership; and firm performance. Ownership structure is among the corporate governance primary mechanisms that has been a focus of many researchers and scholars for few decades. Despite that, there is a lack of prior studies that examine these relationships in the developing countries. In the developed countries context, there are few studies to examine the aforementioned relationship. So, the main objective of this study was to bridge this gap and try to enrich existing literature.
\end{abstract}

Keywords: Corporate Governance, ownership concentration, managerial ownership, government ownership, foreign ownership and institutional ownership and Performance.

\section{Introduction}

Ownership structure is one of the core mechanisms of corporate governance (CG). Ownership structure has been an attention seeker to both scholars and analysts alike. The pioneering study in the theory of the firm on contemporary firm was conducted by Berle and Means (1932). They discussed the conflicts of interest between controllers and managers and concluded that with increasing ownership diffusion, the authority of the shareholders to control management is minimized. Moreover, Demsetz and Lehn (1985) stated that ownership is always endogenously determined for the maximization of firm performance as these benefits all owners. There should be a lack of systematic association between ownership structures and performance as the existence of such a relationship would reflect 
the potential for performance enhancement stemming from reshuffling of ownership structure.

Corporate governance mechanisms are developed to minimize agency costs that are related to the ownership and control separation (Fama \& Jensen, 1983; Jensen \& Meckling, 1976). Prior studies show that governance mechanisms enhance firm value to a certain degree (Weir, Laing \& McKnight, 2002). Similarly, the distinction between ownership and management is common in today's contemporary public corporations. Some of them make use of performance-based incentive contracts to align owners interests with that of managers while others depend on the markets for managerial expertise and corporate control to stop managers from manipulating investments to their own interests (Sing \& Sirmans, 2008). In the same context, the findings of Jensen and Meckling (1979) and Pfeffer and Slanick (1979) provided the first basis of assumptions. Firm value is defined as a function of ownership structure as the latter is linked to corporate governance and it can have positive as well as negative impact upon corporate governance (Jiang, 2004). Consistent to the above are the findings of Lemmon and Lins (2001), who examined the relationship between the two variables through (Tobin-Q) and involved over 800 firms in eight East Asian countries. Their study found a positive relationship between ownership structure and firm performance. As it provide, the main objective of this study is to offer a comprehensive review of the association between ownership structure and firm performance. Therefore, this study is an attempt to achieve this target as will provide below.

\section{Literature Review and Hypotheses Development}

The ownership structure-corporate performance relationship has been receiving significant attention in financial literature (Jiang, 2004; Karaca \& Ekşi, 2012). Among the trademarks of the contemporary firm is the separation of ownership and control (Uwuigbe \& Olusanmi, 2012). Consistent to the context is that fact that ownership structure is a way to minimize the asymmetric information disclosure within capital markets among insiders and outsiders (Wahla et al., 2012). In the same context, Fama and Jensen (1983) and Jensen and Meckling (1976) revealed that the ownership diffusion has a significant effect on the validity of the profit-maximizing aim of firms as the separation control enables corporate managers to exert effort to serve their own interests. Moreover, Demsetz (1983) claimed that ownership structure is an endogenous aspect that maximizes the profit and value of a firm.

Based on the above arguments, managers along with shareholders should have a united objective of increasing firm value (Jensen, 2000). Similarly, ownership structure can be categorized into widely held firms and firms having controlling owners/concentrated ownership where the former category of firms' owners does not have substantial control rights (Haslindar \& Fazilah, 2011). From another perspective, under the resource dependence theory, it is argued that ownership signifies a source of authority that can be utilized to support or to go against management, according to the level of concentration and use (Pfeffer \& Slanick, 1979). Furthermore, Fazlzadeh, Hendi and Mahboubi (2011) claimed that ownership structure plays a key role in firm performance and provides policy makers with insights for enhancing corporate governance system. In the majority of developed countries, ownership structure is significantly dispersed. On the contrary, in the developing countries 
characterized by a weak legal system safeguarding the investors' interests, the ownership structure is concentrated (Ehikioya, 2009). As such, the present study focuses on the examination of the ownership structure-firm performance relationship.

Although the essence of the ownership structure, role is to improve performance, there are extensive studies, ignoring the examination of this role in firm performance. However, there are many studies that confined their study to only the relationship between board characteristics, audit committee, CEO with firm performance (e.g. Abdurrouf, 2011; Avantika, 2011; Chahine \& Safieddine, 2011; Chiang \& Lin, 2011; Chowdhury, 2010; Chugh et al., 2011; Dar et al., 2011; Galbreath, 2010; Heenetigala \& Armstrong, 2011; Jackling \& Johl, 2009; Kang \& Kim, 2011; Khan \& Javid, 2011; Kota \& Tomar, 2010; Lin, 2011; O`Connell \& Cramer, 2010; Rachdi \& Ameur, 2011; Sa'nchez-Marı'n et al., 2010; Shao, 2010; Stanwick \& Stanwick, 2010; Valenti et al., 2011; Yasser, Entebang \& Al Mansor 2011). In addition, only a few researchers have investigated the association between some factors of ownership structure with firm performance (e.g. Akimova \& Schwodiauer, 2004; Chen, Chen \& Chung, 2006; Douma et al., 2006; Ganguli \& Agrawal, 2009; Kapopoulos \& Lazaretou, 2007; Lemmon \& Lins, 2001; Mollah \& Talukdar, 2007; Sánchez-Ballesta \& García-Meca, 2007). Therefore, given the importance of ownership structure, role to attract investors either local or foreign, to ensure future investment, this study investigates the relationship between ownership structure and firm performance.

Based on the extensive discussion and recommendations above, that the true importance of ownership structure to improve the company's performance were addressed by the theoretical, practical and empirical studies along with the ownership structure. In sum, as mentioned above, the goal of the study is to examine the relationship between ownership structure comprising of ownership concentration and types of ownership, including government ownership, managerial ownership, foreign ownership and institutional ownership and firm performance.

\subsection{Ownership Concentration and Firm Performance}

The first element of the CG mechanism of ownership structure examined in this study is the concentration of ownership. It is a reaction to the various levels of legal protection of minority shareholders in the countries (Azam et al., 2011). Ownership concentration is also defined as the proportion of a firm's shares owned by a number of the major shareholders (Sanda et al., 2005). In the same context, ownership concentration is measured by the fraction owned by the five largest shareholders or by the significant shareholders (Karaca \& Ekşi, 2012; Obiyo \& Lenee, 2011; Singh \& Gaur, 2009).

While Berle and Means (1932) revealed a positive correlation between ownership concentration and performance, other studies revealed an absence of relation between the two (Demsetz \& Lehn, 1985; Demsetz, 1983). This does not however negate the importance of ownership concentration as Shleifer and Vishny (1997) claimed that ownership concentration coupled with legal protection forms one of the two key elements that determine corporate governance. In other words, large shareholders can benefit their minority counterparts as they have the authority and incentive to stop managers from expropriation or asset stripping. In this vein, ownership concentration can be considered as a governance mechanism that is 


\section{Macrothink}

Journal of Sociological Research

ISSN 1948-5468

2013, Vol. 4, No.2

efficient. The agency theory postulates that ownership concentration is a critical factor for good corporate governance (Siala et al., 2009). Nevertheless, ownership concentration at a high level offers an opportunity for controlling shareholders and managers to take part in preventing expropriation from minority shareholders (La Porta, Lopez-De-Silanes \& Shleifer, 1999; Morck et al., 1988; Shleifer \& Vishny 1997).

Regarding to above extensive debate among agency theory, resource dependence theory and empirical evidence, the relationship between ownership concentration and firm performance is still inconclusive. Indeed, there many authors around the world who revealed the relationship between concentration ownership and firm performance as positive whether in developed countries. On the other hand, empirically, there are many studies that found a negative relationship between ownership concentration and firm performance. With inconclusive findings found by previous discussions, this study offers extensive review and found both positive and negative association between ownership concentration and firm performance and there are some researchers who found no relationship. For more information, should refer to below tables. 
Table 1.1: Summary of previous literature the discover there is a positive association between Ownership concentration and firm performance

\begin{tabular}{|c|c|c|c|c|}
\hline $\begin{array}{l}\text { Authors and } \\
\text { year }\end{array}$ & Country & Sample & Methods & D.V \\
\hline $\begin{array}{l}\text { Singh \& } \\
\text { Gaur (2009) }\end{array}$ & $\begin{array}{l}\text { China \& } \\
\text { Indian }\end{array}$ & $\begin{array}{l}813 \text { firms, } 400 \text { of which } \\
\text { were India, while } 413 \\
\text { Chinese in } 2007 .\end{array}$ & Multiple regression & $\begin{array}{l}\text { ROA, ROE } \\
\text { \& ROS }\end{array}$ \\
\hline $\begin{array}{lr}\text { Wang } \quad \& \\
\text { Oliver }(2009) \\
\end{array}$ & Australia & $\begin{array}{l}384 \text { firms of the top } 500 \\
\text { companies }\end{array}$ & OLS regressions & firm risk \\
\hline $\begin{array}{l}\text { Siala et al. } \\
(2009)\end{array}$ & Canada & $\begin{array}{l}467 \text { firms non-financial } \\
\text { listed companies during the } \\
\text { period from } 2002 \text { to } 2004 .\end{array}$ & Panel data & Tobin-Q \\
\hline $\begin{array}{l}\text { Jandik \& } \\
\text { Rennie } \\
(2008)\end{array}$ & $\begin{array}{l}\text { The Czech } \\
\text { Republic }\end{array}$ & $\begin{array}{l}\text { All firms were listed on the } \\
\text { Czech stock exchange } \\
\text { during } 1993 \text { to } 2003 \text {. }\end{array}$ & Panel data & $\begin{array}{l}\text { Accounting } \\
\text { performance }\end{array}$ \\
\hline $\begin{array}{l}\text { Kapopoulos } \\
\& \quad \text { Lazaretou } \\
(2007) \\
\end{array}$ & Greek & $\begin{array}{l}175 \text { listed firms through } \\
2000\end{array}$ & Regression & $\begin{array}{l}\text { Tobin-Q \& } \\
\text { profit ration }\end{array}$ \\
\hline $\begin{array}{l}\text { Lin et al. } \\
(2002)\end{array}$ & China & $\begin{array}{l}461 \text { publicly } \text { listed } \\
\text { manufacturing firms in } \\
\text { China between } 1999 \text { and } \\
\text { 2002. }\end{array}$ & $\begin{array}{l}\text { Regression analysis } \\
\text { \& Tobit regressions }\end{array}$ & firm efficient \\
\hline
\end{tabular}

In the developing countries

\begin{tabular}{|c|c|c|c|c|}
\hline $\begin{array}{l}\text { Karaca \& } \\
\text { Ekşi (2012) }\end{array}$ & Turkey & $\begin{array}{l}50 \text { firms from } \\
\text { manufacturing industry on } \\
\text { the Istanbul stock exchange } \\
\text { during } 2005-2008 \text {. }\end{array}$ & Panel regression & $\mathrm{ROA}$ \\
\hline $\begin{array}{l}\text { Obiyo } \& \\
\text { Lenee }(2011) \\
\end{array}$ & Nigeria & $\begin{array}{l}10 \text { firms (Banks, food, } \\
\text { construction and oil firms) } \\
\text { of } 51 \text { firms over } 2004 \text { and } \\
2008 \text {. }\end{array}$ & $\begin{array}{l}\text { The simple linear } \\
\text { regression. }\end{array}$ & $\begin{array}{ll}\text { ROE, } & \text { NPM } \\
\text { \& DY } & \\
\end{array}$ \\
\hline $\begin{array}{l}\text { Azam et al. } \\
(2011)\end{array}$ & Pakistan & $\begin{array}{l}\text { Non-financial data from a } \\
\text { sample of } 14 \text { companies } \\
\text { has been taken for } 6 \text { years } \\
2005-2010 \text {. }\end{array}$ & Canonical regression & $\begin{array}{l}\text { ROA, ROE } \\
\text { \& NPM }\end{array}$ \\
\hline $\begin{array}{l}\text { Khan et al. } \\
(2011)\end{array}$ & Pakistan & $\begin{array}{l}\text { Tobacco sectors through } \\
\text { 2004-2008. }\end{array}$ & Multiple regressions. & ROA \& ROE \\
\hline $\begin{array}{l}\text { Mandac1 \& } \\
\text { Gumus } \\
(2010) \\
\end{array}$ & Turkey & $\begin{array}{l}\text { Non-financial companies } \\
\text { on the ISE during } 2005 . \\
203 \text { companies. }\end{array}$ & Multiple regressions. & $\begin{array}{l}\text { ROA } \\
\text { Tobin-Q }\end{array}$ \\
\hline $\begin{array}{l}\text { Ganguli \& } \\
\text { Agrawal } \\
(2009) \\
\end{array}$ & India. & $\begin{array}{l}100 \text { firms which were } \\
\text { listed in Indian Stock } \\
\text { Exchange through } 2007 .\end{array}$ & OLS \& SLS. & Tobin-Q \\
\hline $\begin{array}{l}\text { Imam } \& \\
\text { Malik (2007) }\end{array}$ & $\begin{array}{l}\text { Banglades } \\
\mathrm{h}\end{array}$ & $\begin{array}{l}\text { All non-financial through } \\
2000-2003\end{array}$ & $\begin{array}{l}\text { The multiple } \\
\text { regression }\end{array}$ & Tobin-Q \\
\hline Ehikioya & Nigeria & 107 firms quoted in the & Regression & ROA, ROE, \\
\hline
\end{tabular}




\begin{tabular}{|c|c|c|c|}
\hline (2009) & & $\begin{array}{l}\text { Nigerian Stock Exchange } \\
\text { for the fiscal years } 1998 \text { to } \\
2002 \text {. }\end{array}$ & $\begin{array}{ll}\text { Tobin-Q } & \& \\
\text { PE ratio } & \\
\end{array}$ \\
\hline $\begin{array}{l}\text { Roszaini \& } \\
\text { Mohammad } \\
(2006)\end{array}$ & Malaysia & $\begin{array}{l}347 \text { companies listed on } \\
\text { the main board of the } \\
\text { KLSE between } 1996 \text { and } \\
2000\end{array}$ & Tobin-Q \\
\hline
\end{tabular}

Table 1.2: Summary of previous studies that find there is a negative association between Ownership concentration and firm performance

\begin{tabular}{|c|c|c|c|c|}
\hline $\begin{array}{l}\text { Authors and } \\
\text { year }\end{array}$ & Country & Sample & Methods & D.V \\
\hline $\begin{array}{l}\text { Garci'a-Meca \& } \\
\text { Sa'nchez-Ballesta } \\
\text { (2011) }\end{array}$ & Spanish & $\begin{array}{l}\text { Non-financial firms listed } \\
\text { on the Madrid Stock } \\
\text { Exchange that it was } 254 \\
\text { firms -year observation } \\
\text { for the period from } 1999 \\
\text { to } 2002 \text {. }\end{array}$ & $\begin{array}{l}\text { Panel data } \\
\text { regressions }\end{array}$ & Tobin's-Q \\
\hline $\begin{array}{ll}\text { Millet-Reyes } & \& \\
\text { Zhao (2010) } & \\
\end{array}$ & France & $\begin{array}{lr}665 & \text { non-financial } \\
\text { firm-year } & \text { observations } \\
\text { covering } 174 \quad \text { French } \\
\text { companies from 28 } \\
\text { industries over the period } \\
\text { 2000-2004. }\end{array}$ & $\begin{array}{l}\text { Multiple } \\
\text { regressions. }\end{array}$ & $\begin{array}{l}\text { OCF, ROA \& } \\
\text { Tobin's Q }\end{array}$ \\
\hline Hu et al. (2010) & China & $\begin{array}{l}304 \text { from } 1271 \text { firms } \\
\text { listed on the Shanghai } \\
\text { and Shenzhen Stock } \\
\text { Exchange that it was } \\
\text { selected during } 2003 \text {. }\end{array}$ & $\begin{array}{l}\text { Multivariate } \\
\text { regression and } \\
\text { this study was } \\
\text { using SEM. } \\
\end{array}$ & Tobin-Q \\
\hline $\begin{array}{l}\text { Filatotchev et al. } \\
(2007)\end{array}$ & $\begin{array}{l}\text { Poland \& } \\
\text { Hungary }\end{array}$ & $\begin{array}{l}500 \text { largest non-financial } \\
\text { firms in Poland And } 250 \\
\text { largest companies from } \\
\text { the Hungary. }\end{array}$ & $\begin{array}{l}\text { Structural } \\
\text { Equation } \\
\text { Modeling } \\
(\text { SEM). }\end{array}$ & ROS \& ROA \\
\hline Belkhir (2005) & US & $\begin{array}{l}260 \text { banks that were } \\
\text { through } 2002 \text {. }\end{array}$ & $\overline{\mathrm{OLS}}$ & Tobin-Q \\
\hline \multicolumn{5}{|c|}{ In the developing countries } \\
\hline $\begin{array}{ll}\text { Roszaini } & \text { \& } \\
\text { Mohammad } & \\
(2006) & \\
\end{array}$ & Malaysia & $\begin{array}{l}347 \text { companies listed on } \\
\text { the main board of the } \\
\text { KLSE between } 1996 \text { and } \\
2000\end{array}$ & OLS regression & $\overline{\mathrm{ROA}}$ \\
\hline
\end{tabular}


Table 1.3: Summary of previous authors that disclose there is not association between Ownership concentration and firm performance

\begin{tabular}{|c|c|c|c|c|}
\hline $\begin{array}{l}\text { Authors and } \\
\text { year }\end{array}$ & Country & Sample & Methods & D.V \\
\hline \multirow{2}{*}{$\begin{array}{l}\text { Shan } \\
\text { \&McIver } \\
(2011) \\
\end{array}$} & China & \multirow{2}{*}{ 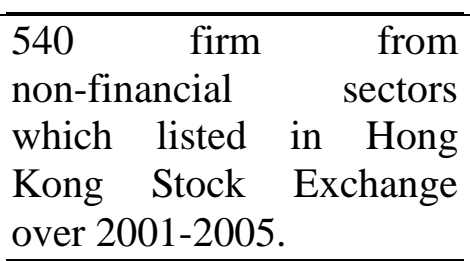 } & \multirow{2}{*}{$\begin{array}{lr}\text { Ordinary } & \text { least } \\
\text { squares fixed effects } \\
\text { methods. }\end{array}$} & \multirow[t]{2}{*}{ Tobin-Q } \\
\hline & & & & \\
\hline \multirow{2}{*}{$\begin{array}{l}\text { Sánchez-Balle } \\
\text { sta \& } \\
\text { García-Meca } \\
(2007)\end{array}$} & European & 33 studies around the & \multirow{2}{*}{$\begin{array}{lr}\text { Linear regressions } \\
\text { and } & \text { non-linear } \\
\text { regressions. }\end{array}$} & \multirow{2}{*}{$\begin{array}{lr}\text { RAO, ROE, } \\
\text { ROS } \quad \text { \& } \\
\text { Tobin-Q }\end{array}$} \\
\hline & & world from 1988 to 2006. & & \\
\hline \multirow[t]{2}{*}{$\begin{array}{lll}\begin{array}{l}\text { Earle } \\
(2005)\end{array} & \text { et al. } \\
\end{array}$} & Hungary & $\begin{array}{l}\text { All firms that were listed } \\
\text { on the Budapest Stock }\end{array}$ & \multirow[t]{2}{*}{ Multiple regressions } & \multirow{2}{*}{$\begin{array}{ll}\text { ROE } & \& \\
\text { operation } & \\
\text { efficiency } & \\
\end{array}$} \\
\hline & & $\begin{array}{l}\text { Exchange over } 1996 \text { to } \\
2001 \text {. }\end{array}$ & & \\
\hline \multicolumn{5}{|c|}{ In the developing countries } \\
\hline \multirow{2}{*}{$\begin{array}{l}\text { Karaca \& } \\
\text { Ekşi (2012) } \\
\end{array}$} & Turkey & \multirow{2}{*}{$\begin{array}{lr}50 \quad \text { firms } & \text { from } \\
\text { manufacturing industry on } \\
\text { the Istanbul } & \text { stock } \\
\text { exchange } & \text { during } \\
2005-2008 . & \end{array}$} & \multirow[t]{2}{*}{ Panel regression. } & \multirow[t]{2}{*}{ Tobin-Q } \\
\hline & & & & \\
\hline Najjar (2012) & Bahrain & $\begin{array}{l}5 \text { insurance firms during } \\
20052010 \text {. }\end{array}$ & $\begin{array}{l}\text { E-views program and } \\
\text { the method the } \\
\text { Pooled data. }\end{array}$ & ROE \\
\hline \multirow[t]{2}{*}{$\begin{array}{l}\text { Wahla et al. } \\
(2012)\end{array}$} & Pakistan & \multirow{2}{*}{$\begin{array}{l}138 \text { firms of seven } \\
\text { non-financial sectors of } \\
\text { Karachi stock exchange } \\
\text { through 2008-2010. }\end{array}$} & Multiple regressions. & \multirow[t]{2}{*}{ Tobin-Q } \\
\hline & & & & \\
\hline \multirow{2}{*}{$\begin{array}{l}\text { Tsegba \& } \\
\text { Ezi-Herbert } \\
(2011) \\
\end{array}$} & Nigeria & \multirow{3}{*}{$\begin{array}{l}73 \text { firms listed on the } \\
\text { Nigeria Stock Exchange } \\
\text { during the period } \\
2001-2007 \text {. } \\
\text { 137 listed firms of Tehran } \\
\text { stock exchange within the } \\
\text { period } 2001 \text { to } 2006 .\end{array}$} & \multirow[t]{2}{*}{ OLS } & \multirow{2}{*}{$\begin{array}{lr}\text { Market } & \text { price } \\
\text { per } & \text { share } \\
\text { (MPS) } & \& \\
\text { EPS) } & \\
\end{array}$} \\
\hline & & & & \\
\hline $\begin{array}{l}\text { Fazlzadeh et } \\
\text { al. (2011) } \\
\end{array}$ & Iran & & $\begin{array}{lr}\text { Panel } & \text { data } \\
\text { regression } & \text { analysis } \\
\text { method. } & \\
\end{array}$ & $\mathrm{ROA}$ \\
\hline \multirow[t]{3}{*}{$\begin{array}{l}\text { Ibrahim et al. } \\
(2010)\end{array}$} & Pakistan & \multirow{3}{*}{$\begin{array}{l}\text { The data was selected } \\
\text { from two manufacturing } \\
\text { sectors Chemical and } \\
\text { Pharmaceutical } \\
\text { Pakistan from } 2005 \text { to } \\
\text { 2009. } \\
\end{array}$} & Multiple regressions. & \multirow[t]{3}{*}{ ROA \& ROE } \\
\hline & & & & \\
\hline & & & & \\
\hline \multirow{2}{*}{\multicolumn{2}{|c|}{$\begin{array}{l}\text { Bektas } \\
\text { Kaymak } \\
(2009) \\
\end{array}$}} & \multirow{2}{*}{$\begin{array}{l}\text { All banks sectors the } \\
\text { period was during } \\
\text { 1994-2004. }\end{array}$} & \multirow{2}{*}{$\begin{array}{l}\text { Cross-sectional } \\
\text { regression analysis. }\end{array}$} & \multirow{2}{*}{$\begin{array}{ll}\text { ROA } & \& \\
\text { Tobin-Q } & \\
\end{array}$} \\
\hline & & & & \\
\hline Al-Hussain \& & Saudi & Nine banks & Multiple regression & ROA \\
\hline
\end{tabular}




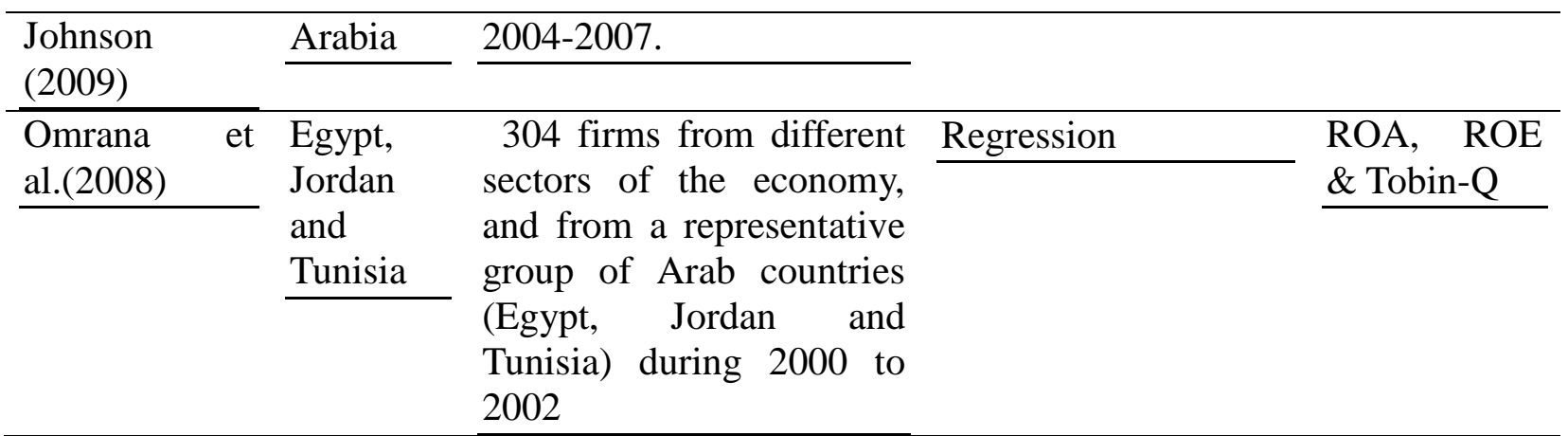

Therefore, this study attempted to contribute to literature by introducing the following hypotheses to be tested.

H1: There is a negative relationship between the ownership concentration and firm performance.

\subsection{Managerial Ownership and Firm Performance}

The second vital factor of quality of ownership structure is the managerial ownership. The managerial ownership is represented as the proportion of shared owned in the firm by insiders and board members or insider ownership (Liang et al., 2011; Mandac1 \& Gumus, 2010; Wahla et al., 2012). While insider ownership appears to act as an effective corporate mechanism, managerial ownership is considered by Jensen and Meckling (1976) as a signal to align the shareholders' interests with that of the manager's. On a similar note to the latter contention, Khan et al. (2011) and Shleifer and Vishny (1988) revealed that high managerial ownership may lead to management entrenchment as they have less BOD governance and market discipline for corporate control.

There are theoretical and empirical evidence that examined the relationship between managerial ownership and firm's performance and revealed mixed findings. This inconclusive finding will be reviewed in the following discussion. First of all, the agency theory perspective is discussed - Jensen and Meckling (1976) stated that managerial ownership leads to the improvement of manager-owner agency conflict as managers are also the owners of a majority of firm shares and hence they are encouraged to maximize job performance to realize superior performance. However, Demsetz (1983) and Fama and Jensen (1983) considered high managerial ownership as the cause of management entrenchment and thus leading to serious agency problems.

Moreover, Jensen and Meckling (1976) claimed that agency cost and managerial ownership are negatively related, while firm's performance and managerial ownership are positively so. On the other hand, Morck et al. (1998) and Wahla et al. (2012) stated that high managerial stake on firm ownership can act as a mechanism that influences the alignment of interests between managers and owners and eventually affect firm market value . On the other hand, the resource dependence theory supports a partnership with external resources because they provide the company with multiple sources and different experiences as they work to maximize shareholder rights and all parties associated with the company. It focuses on the involvement of all confiscated resources and merges them together in order to make the most of the experience and confiscation, which in turn helps to achieve the goals of the beneficiaries of the company. Therefore, the large ownership by members of the board do not 


\section{Macrothink}

help to improve performance of companies (Pfeffer, 1972).

Regarding the above discussion, the relationship between managerial ownership and firm performance should be negative. For this logic, there are many researchers in developed countries that have verified the relationship between managerial ownership and firm performance. They have been revealing a negative association between them. On the other hand, this section also highlights some evidence in the developing countries. There were many researchers in developing countries that verified the relationship between managerial ownership and firm performance and found a negative association between them. For further information, should refer to below tables.

Table 1.4: Summary of previous studies that reveal there is a positive relationship between Managerial ownership and firm performance

\begin{tabular}{|c|c|c|c|c|}
\hline $\begin{array}{l}\text { Authors and } \\
\text { year }\end{array}$ & Country & Sample & Methods & D.V \\
\hline $\begin{array}{ll}\text { Leung } \quad \& \\
\text { Horwitz } \\
(2010) \\
\end{array}$ & China & $\begin{array}{l}506 \text { non-financial firms } \\
\text { that were listed on the } \\
\text { Hong Kong Stock } \\
\text { Exchange over 1997-1998. }\end{array}$ & Panel regression. & $\begin{array}{l}\text { Market } \\
\text { adjusted }\end{array}$ \\
\hline $\begin{array}{l}\text { Bhagat \& } \\
\text { Bolton (2009) }\end{array}$ & US & $\begin{array}{l}1500 \text { large firms during } \\
\text { from } 1999 \text { to } 2007 \text {. }\end{array}$ & Logit regression & $\begin{array}{l}\text { ROA } \\
\text { Tobin-Q }\end{array}$ \\
\hline $\begin{array}{l}\text { Bauer et al. } \\
(2009)\end{array}$ & US & \begin{tabular}{lr}
113 & \multicolumn{2}{c}{ observations } \\
(firm-years) & during 2004 \\
and 2006. &
\end{tabular} & OLS regression & $\begin{array}{l}\text { Tobin-Q, } \\
\text { ROA, ROE \& } \\
\text { NPM }\end{array}$ \\
\hline $\begin{array}{ll}\text { Juras } & \& \\
\text { Hinson } & \\
(2008) & \\
\end{array}$ & US & $\begin{array}{l}\text { Public banks of available } \\
\text { data and commercial } \\
\text { database that the period } \\
\text { was during 1999-2003. }\end{array}$ & OLS regressions & Efficacy ratio \\
\hline Dey (2008) & U.S & $\begin{array}{l}371 \text { firms through } 2000 \text { to } \\
2001 \text {. }\end{array}$ & $\begin{array}{l}\text { Multiple } \\
\text { regressions. }\end{array}$ & $\begin{array}{l}\text { ROA } \\
\text { Tobin-Q }\end{array}$ \\
\hline $\begin{array}{l}\text { Bhagata \& } \\
\text { Bolton }(2008) \\
\end{array}$ & US & $\begin{array}{l}\text { All firms through } 990 \text { to } \\
2004 \text {. }\end{array}$ & $\begin{array}{l}\text { Multinomial logit } \\
\text { regression }\end{array}$ & $\begin{array}{l}\text { ROA } \\
\text { Tobin-Q }\end{array}$ \\
\hline $\begin{array}{l}\text { Kapopoulos } \\
\& \text { Lazaretou } \\
(2007) \\
\end{array}$ & Greek & $\begin{array}{l}175 \text { Greek listed firms } \\
\text { through } 2000 .\end{array}$ & Regression & $\begin{array}{ll}\text { Tobin-Q \& } & \& \\
\text { profit ration }\end{array}$ \\
\hline $\begin{array}{l}\text { Sánchez-Balle } \\
\text { sta \& } \\
\text { García-Meca } \\
(2007) \\
\end{array}$ & European & $\begin{array}{l}33 \text { studies around the } \\
\text { world from } 1988 \text { to } 2006 \text {. }\end{array}$ & $\begin{array}{l}\text { Linear } \\
\text { regressions and } \\
\text { non-linear } \\
\text { regressions. } \\
\end{array}$ & $\begin{array}{lr}\text { RAO, } & \text { ROE, } \\
\text { ROS } & \& \\
\text { Tobin-Q } & \\
\end{array}$ \\
\hline $\begin{array}{l}\text { Florackis } \\
(2005)\end{array}$ & UK & $\begin{array}{l}962 \text { non-financial large } \\
\text { firms that were listed on } \\
\text { the UK Stock Exchange. }\end{array}$ & $\begin{array}{l}\text { Multiple } \\
\text { regressions. }\end{array}$ & Tobin-Q \\
\hline \multicolumn{5}{|c|}{ In the developing countries } \\
\hline $\begin{array}{l}\text { Uwuigbe \& } \\
\text { Olusanmi } \\
(2012)\end{array}$ & Nigeria. & $\begin{array}{l}31 \text { firms of all firms in } \\
\text { financial sector during } \\
2006-2010 \text {. }\end{array}$ & $\begin{array}{l}\text { Multivariate } \\
\text { multiple } \\
\text { regression. }\end{array}$ & $\mathrm{ROA}$ \\
\hline Swamy & India & 83 unlisted families over & $\begin{array}{lr}\text { Panels Regression } \\
\text { GLS. } \quad \text { Primary }\end{array}$ & ROA \& ROE \\
\hline
\end{tabular}




\begin{tabular}{|c|c|c|c|c|}
\hline (2011) & & 2008 until 2010. & data & \\
\hline $\begin{array}{l}\text { Hasnah } \\
\text { (2009) }\end{array}$ & Malaysia & $\begin{array}{lll}520 & \text { companies } & \text { during } \\
2007 & & \\
\end{array}$ & $\begin{array}{l}\text { Multiple } \\
\text { regression }\end{array}$ & $\begin{array}{l}\text { Tobin` } \mathrm{Q} \text { and } \\
\text { ROA }\end{array}$ \\
\hline $\begin{array}{l}\text { Sing } \\
\text { Sirmans } \\
(2008) \\
\end{array}$ & Singapore & $\begin{array}{l}228 \text { Real Estate firms that } \\
\text { were listed on the } \\
\text { Singapore Stock Exchange } \\
\text { that the period was during } \\
2000-2006 \text {. }\end{array}$ & SLS. & Tobin-Q \\
\hline $\begin{array}{l}\text { Chung et al. } \\
\text { (2008) }\end{array}$ & Korea & $\begin{array}{l}377 \text { firms that the period } \\
\text { was during } 1999 \text { to } 2005 \text {. }\end{array}$ & $\begin{array}{l}\text { Multiple } \\
\text { regressions }\end{array}$ & ROA \\
\hline $\begin{array}{l}\text { Ehikioya } \\
(2009)\end{array}$ & Nigerian & $\begin{array}{l}107 \text { firms quoted in the } \\
\text { Nigerian Stock Exchange } \\
\text { for the fiscal years } 1998 \text { to } \\
2002 \text {. }\end{array}$ & Regression & $\begin{array}{l}\text { ROA, ROE, } \\
\text { Tobin-Q \& PE }\end{array}$ \\
\hline $\begin{array}{l}\text { Imam \& \& } \\
\text { Malik (2007) }\end{array}$ & $\begin{array}{l}\text { Banglades } \\
\mathrm{h}\end{array}$ & $\begin{array}{l}\text { All non-financial over } \\
2000-2003 \text {. }\end{array}$ & $\begin{array}{l}\text { The multiple } \\
\text { regression }\end{array}$ & Tobin-Q \\
\hline $\begin{array}{l}\text { Kyereboah-C } \\
\text { oleman \& } \\
\text { Biekpe (2006) }\end{array}$ & $\begin{array}{l}\text { Ghana } \\
\text { firms }\end{array}$ & $\begin{array}{l}\text { All non-traditional export } \\
\text { sectors that the period was } \\
\text { covering from } 1995 \text { to } \\
2004 \text {. }\end{array}$ & & ROA \& ROE \\
\hline $\begin{array}{l}\text { Akimova \& } \\
\text { Schwodiauer } \\
(2004)\end{array}$ & Ukraine & $\begin{array}{l}202 \text { medium and large } \\
\text { industrial companies in } \\
\text { Ukraine. The period of } \\
\text { study was during 1998- } \\
2000 \text {. }\end{array}$ & OLS. & $\begin{array}{ll}\begin{array}{l}\text { Sales } \\
\text { employee }\end{array} & \text { per } \\
\end{array}$ \\
\hline
\end{tabular}


Table 1.5: Summary of previous studies that there is a negative relationship between

Managerial ownership and firm performance

\begin{tabular}{|c|c|c|c|c|}
\hline $\begin{array}{l}\text { Authors } \\
\text { and year }\end{array}$ & Country & Sample & Methods & D.V \\
\hline $\begin{array}{l}\text { Irina \& } \\
\text { Nadezhda } \\
(2009)\end{array}$ & German & $\begin{array}{l}270 \text { companies for the } \\
\text { period of 2000-2006. }\end{array}$ & Regression. & $\begin{array}{l}\text { Tobin-Q \& } \\
\text { ROA }\end{array}$ \\
\hline $\begin{array}{l}\text { Switzer \& } \\
\text { Tangb } \\
(2009)\end{array}$ & US & $\begin{array}{l}245 \text { small-cap firms through } \\
2000 \text { to } 2004 \text {. }\end{array}$ & SLS & Tobin-Q \\
\hline $\begin{array}{ll}\text { Juras } \quad \& \\
\text { Hinson } \\
(2008) \\
\end{array}$ & US & $\begin{array}{l}\text { Public banks available data } \\
\text { and commercial database } \\
\text { that the period was during } \\
1999-2003 \text {. }\end{array}$ & OLS regression. & ROA \\
\hline $\begin{array}{l}\text { Belkhir } \\
(2005)\end{array}$ & US & $\begin{array}{l}260 \text { banks that were through } \\
2002 \text {. }\end{array}$ & OLS & Tobin-Q \\
\hline \multicolumn{5}{|c|}{ In the developing countries } \\
\hline $\begin{array}{l}\text { Wahla et al. } \\
(2012) \\
\end{array}$ & Pakistan & $\begin{array}{l}7 \text { non-financial sectors of } \\
\text { Karachi stock exchange. } \\
\text { Total number of companies } \\
\text { under these sectors is } 138 \text {. }\end{array}$ & Multiple regression & Tobin-Q \\
\hline $\begin{array}{l}\text { Tsegba \& } \\
\text { Ezi-Herbert } \\
(2011) \\
\end{array}$ & Nigeria & $\begin{array}{lrr}73 \text { firms } & \text { listed } & \text { on the } \\
\text { Nigeria Stock } & \text { Exchange } \\
\text { during } & \text { the } & \text { period } \\
2001-2007 . & \end{array}$ & OLS & $\begin{array}{lr}\text { Market } & \text { price } \\
\text { per } & \text { share } \\
\text { (MPS) } & \& \\
\text { EPS } & \end{array}$ \\
\hline $\begin{array}{l}\text { Liang et al. } \\
(2011)\end{array}$ & Taiwan & $\begin{array}{l}907 \text { firm-year observations } \\
\text { are in the growth stage, } \\
2,654 \text { are in the maturity } \\
\text { stage, and } 882 \text { are in the } \\
\text { stagnation stage. The period } \\
\text { of study was during 1999- } \\
2008 \text {. }\end{array}$ & Panel data. & $\begin{array}{ll}\text { ROA } & \& \\
\text { Tobin-Q } & \\
\end{array}$ \\
\hline $\begin{array}{l}\text { Shahab-u- } \\
\text { Din \& } \\
\text { Javid } \\
(2011) \\
\end{array}$ & Pakistan & $\begin{array}{ll}60 \text { firm non-financial firms } \\
\text { of manufacturing firms } \\
\text { during 2000-2007. }\end{array}$ & 2SLS regression & $\begin{array}{l}\text { ROA, ROE } \\
\text { \& Tobin-Q } \\
\end{array}$ \\
\hline $\begin{array}{l}\text { Mandacı } \\
\& \quad \text { Gumus } \\
(2010)\end{array}$ & Turkey & $\begin{array}{l}\text { Non-financial companies on } \\
\text { the ISE during 2005. } 203 \\
\text { companies. }\end{array}$ & Multiple regressions. & $\begin{array}{ll}\text { ROA } & \& \\
\text { Tobin-Q } & \\
\end{array}$ \\
\hline $\begin{array}{l}\text { Muravyev } \\
\text { et al. } \\
(2010) \\
\end{array}$ & Ukraine & $\begin{array}{l}916 \text { companies with a total } \\
\text { of } 3,012 \text { observations over a } \\
\text { five-year period from } 2002 \\
\text { to } 2006 \text {. }\end{array}$ & Logit Regressions & 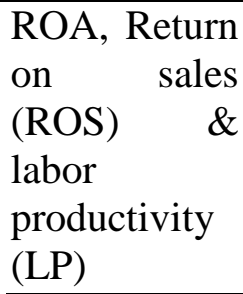 \\
\hline $\begin{array}{l}\text { Uadiale } \\
(2010) \\
\end{array}$ & Nigeria & $\begin{array}{l}30 \text { quoted companies for the } \\
\text { period } 2007 .\end{array}$ & OLS regression. & $\begin{array}{l}\text { ROE } \\
\text { ROCE } \\
\end{array}$ \\
\hline
\end{tabular}




\begin{tabular}{|c|c|c|c|c|}
\hline $\begin{array}{l}\text { Abdullah et } \\
\text { al. (2008) }\end{array}$ & Pakistan & $\begin{array}{l}50 \text { listed firms for the period } \\
2002-2005 \text {. }\end{array}$ & $\begin{array}{ll}\text { The } & \text { regression } \\
\text { analysis. } & \end{array}$ & $\begin{array}{l}\text { ROA } \\
\text { MVA }\end{array}$ \\
\hline $\begin{array}{l}\mathrm{Al} \\
\text { Farooque }\end{array}$ & $\begin{array}{l}\text { Banglade } \\
\text { sh }\end{array}$ & $\begin{array}{l}\text { All listed financial and } \\
\text { non-financial that was listed }\end{array}$ & SLS regression. & $\begin{array}{l}\text { Market-to-bo } \\
\text { ok value }\end{array}$ \\
\hline $\begin{array}{ll}\text { et } & \text { al. } \\
(2007) & \end{array}$ & & $\begin{array}{l}\text { on Dhaka Stock Exchange. } \\
\text { The sample was based on } \\
723 \text { companies covering } 8 \\
\text { years from } 1995 \text { to } 2002 \text {. }\end{array}$ & & \\
\hline Dwivedi \& & India & 340 large listed Indian firms & Regression. & Tobin-Q \\
\hline Jain (2005) & & $\begin{array}{l}\text { for the period } 1997-2001 \\
\text { spread across } 24 \text { industry } \\
\text { groups. }\end{array}$ & & \\
\hline
\end{tabular}

Table 1.6: Summary of previous literature that finds there is no relationship between Managerial ownership and firm performance

\begin{tabular}{|c|c|c|c|c|}
\hline Authors & Country & Sample & Methods & D.V \\
\hline Siala et al. & Canada & $\begin{array}{lll}467 & \text { firms } & \text { non-financial }\end{array}$ & Panel data & Tobin-Q \\
\hline$(2009)$ & & $\begin{array}{l}\text { listed companies during the } \\
\text { period from } 2002 \text { to } 2004 \text {. }\end{array}$ & & \\
\hline Juras \& & US & Public banks of available & OLS regressions & ROE \\
\hline $\begin{array}{l}\text { Hinson } \\
(2008) \\
\end{array}$ & & $\begin{array}{l}\text { data and commercial } \\
\text { database that the period was } \\
\text { during 1999-2003. }\end{array}$ & & \\
\hline \multicolumn{5}{|c|}{ In the developing countries } \\
\hline $\begin{array}{l}\text { Mohd } \\
(2011)\end{array}$ & Malaysia & $\begin{array}{l}162 \text { non-financial firms } \\
\text { through } 2006 \text { and } 2008 .\end{array}$ & Multiple regressions. & $\mathrm{ROA}$ \\
\hline Nuryanah & Indonesia & From 315 listed companies, & Multiple regressions & Tobin-Q \\
\hline $\begin{array}{l}\& \quad \text { Islam } \\
(2011) \\
\end{array}$ & & $\begin{array}{l}\text { only } 46 \text { companies were } \\
\text { selected for this study. The } \\
\text { sample data was selected } \\
\text { from financial sectors over } \\
2002-2004 \text {. }\end{array}$ & & \\
\hline Garci'a-Me & Spanish & Non-financial firms listed on & Panel & Tobin's-Q \\
\hline $\begin{array}{l}\text { ca } \quad \& \\
\text { Sa'nchez-B } \\
\text { allesta } \\
(2011)\end{array}$ & & $\begin{array}{l}\text { the Madrid Stock Exchange } \\
\text { that it was } 254 \text { firms -year } \\
\text { observation for the period } \\
\text { from } 1999 \text { to } 2002 \text {. }\end{array}$ & regressions & \\
\hline $\begin{array}{l}\text { NazliAnum } \\
(2010)\end{array}$ & Malaysia & 87 non-companies in 2001. & Multiple regression & Tobin-Q \\
\hline $\begin{array}{l}\text { Chang } \\
(2009) \\
\end{array}$ & Taiwan & $\begin{array}{l}\text { Public traded firms during } \\
\text { 2002-2007. }\end{array}$ & Logistic regression. & $\begin{array}{l}\text { financial } \\
\text { distress }\end{array}$ \\
\hline & & & & firms \\
\hline $\begin{array}{l}\text { Zubaidah, } \\
\text { Nurmala \& } \\
\text { Kamaruza }\end{array}$ & Malaysia & 75 companies during 2003 & Multiple regression & VA \\
\hline
\end{tabular}




\begin{tabular}{|c|c|c|c|c|}
\hline $\operatorname{an}(2009)$ & & & & \\
\hline $\begin{array}{l}\text { Abdullah et } \\
\text { al. (2008) }\end{array}$ & Pakistan & $\begin{array}{l}50 \text { listed firms for the period } \\
2002-2005 \text {. }\end{array}$ & $\begin{array}{ll}\text { The } & \text { regression } \\
\text { analysis. } & \end{array}$ & $\begin{array}{l}\text { ROE \& } \\
\text { Tobin-Q }\end{array}$ \\
\hline $\begin{array}{l}\text { Kyereboah- } \\
\text { Coleman \& } \\
\text { Biekpe } \\
(2006) \\
\end{array}$ & Ghana & $\begin{array}{l}\text { All non-traditional export } \\
\text { sectors that the period was } \\
\text { covering from } 1995 \text { to } 2004 \text {. }\end{array}$ & Panel regression. & $\begin{array}{l}\text { export } \\
\text { sales growth }\end{array}$ \\
\hline $\begin{array}{l}\text { Roszaini \& } \\
\text { Mohamma } \\
\text { d (2006) } \\
\end{array}$ & Malaysia & $\begin{array}{l}347 \text { companies listed on the } \\
\text { main board of the KLSE } \\
\text { between } 1996 \text { and } 2000\end{array}$ & OLS regression & ROA \\
\hline $\begin{array}{l}\text { Joher \& Ali } \\
(2005) \\
\end{array}$ & Malaysia & $\begin{array}{l}100 \text { firms over } 5 \text { years from } \\
1997 \text { to } 2001 .\end{array}$ & $\begin{array}{l}\text { Cross-sectional } \\
\text { annual }\end{array}$ & ROA \\
\hline $\begin{array}{l}\text { Sheu \& } \\
\text { Yang } \\
(2005) \\
\end{array}$ & Taiwan & $\begin{array}{l}333 \text { Taiwanese electronics } \\
\text { firms that were listed on the } \\
\text { Taiwan Stock Exchange } \\
\text { through } 1996 \text { to } 2000 \text {. }\end{array}$ & Regression & Productivity \\
\hline
\end{tabular}

To empirically re-examine this relationship, this study proposes the following hypotheses.

H2: There is a positive relationship between the managerial ownership and firm performance.

\subsection{Government Ownership and Firm Performance}

The third important issue of value of ownership structure is government ownership. The government ownership is measured by the ratio of shares owned by the government in the firm (Imam \& Malik, 2007; Irina \& Nadezhda, 2009; NazliAnum, 2010; NurulAfzan \& Rashidah, 2011; Rhoades, Juleff \& Paton, 2001) revealed that the choice of suitable governance mechanisms among owners and managers will guarantee the alignment of their interests.

Under the agency theory, government ownership can be a solution to the issue of asymmetry of information provided to investors concerning the firm value and the shares owned by the state can align the interest between owners and managers (Jensen \& Meckling, 1979). Generally, the government is capable of obtaining information from sources and it has a convenient access to various financing organizations and non-state firms (Eng \& Mak, 2003). In addition, the aim of the government is mainly linked to the nation's well-being. However, according to Mak and $\mathrm{Li}$ (2001), the government will not be as likely to be active in investment monitoring in GLS. More importantly, the GLCs adoption of strong governance may be hindered by factors including weaker accountability for financial performance, easier access to financing, lack of exposure to market for corporate control and weaker monitoring by shareholders. Theoretically and empirically, there has been a growing researcher to examine the relationship between government ownership and firm performance. However, the result is still mixed. For explanation of these mixed findings, the next paragraphs provide a justification.

From another perspective, under resource dependence theory, outsourcing helps to provide established sources of finding a variety of different and varied experience qualifications that work to reduce the cost of capital. It also works to provide an efficient control mechanism of 
several aspects in order to help create a favourable working and effective environment. This, in turn, works to improve the performance of the company (Pfeffer, 1972). And hence, the current study expects that the government is one of the most important outsourcing mechanism and effective and efficient in improving the function of the companies.

Regarding both agency theory and resource dependence theory, the relationship between government ownership and firm performance should be positive. However, there is lack of empirical research that examined the relationship between government and firm performance. They revealed a positive relationship in the developed countries. On the other hand, very little evidence has revealed a negative association between government ownership and firm performance. . Finally, there is some studies that found there is no significant relationship between government ownership and firm performance. For more details, you can refer to provide below table;

Table 1.7: Summary of previous studies that find there is a positive relationship between Government ownership and firm

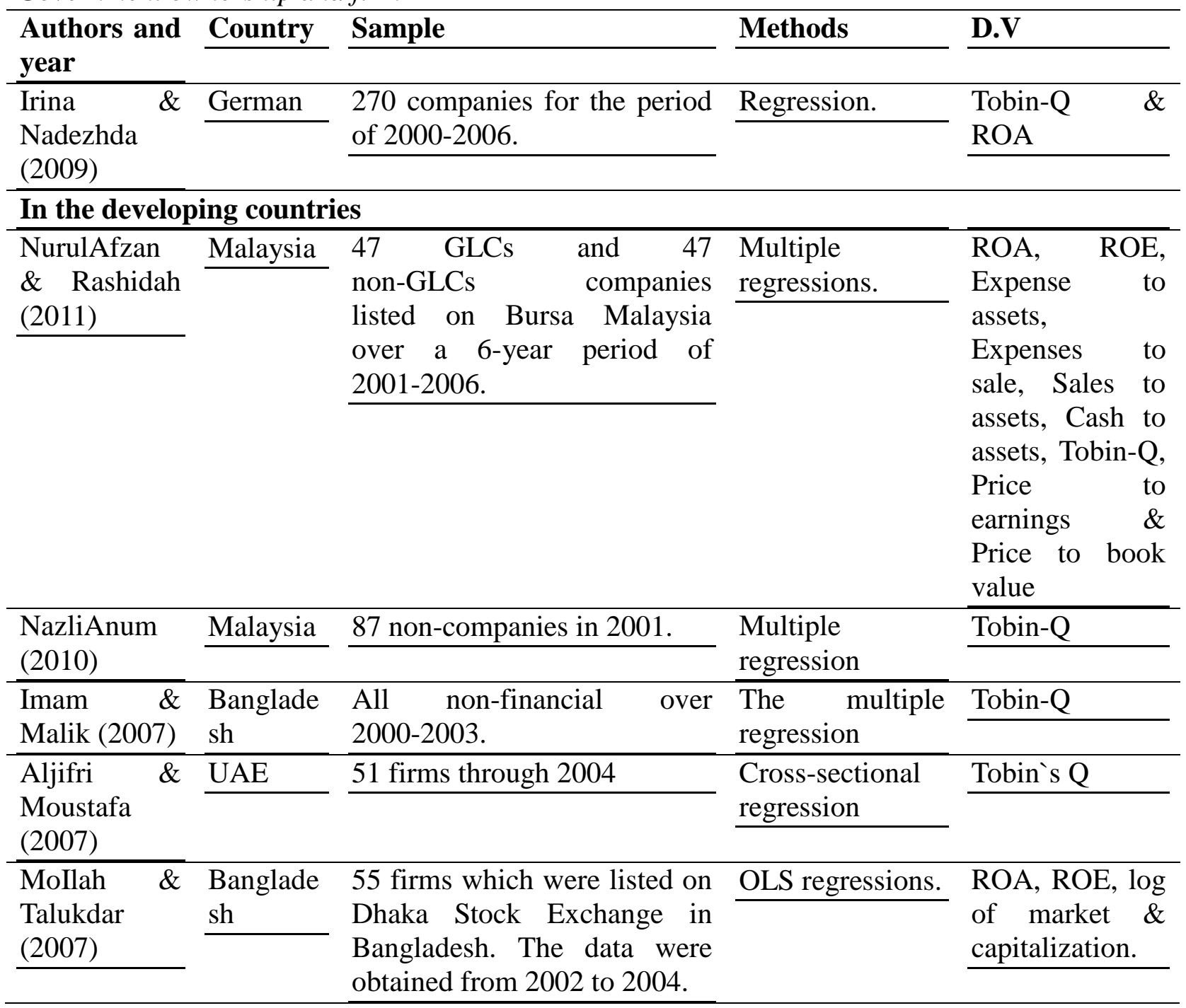

Table 1.8: Summary of prior writers that find there is a negative relationship between Government ownership and firm 


\begin{tabular}{|c|c|c|c|c|}
\hline $\begin{array}{l}\text { Authors } \\
\text { and year }\end{array}$ & Content & Sample & Methods & D.V \\
\hline \multicolumn{5}{|c|}{ In the developing countries } \\
\hline $\begin{array}{l}\text { Al Farooque } \\
\text { et al. (2007) }\end{array}$ & $\begin{array}{l}\text { Banglade } \\
\text { sh }\end{array}$ & $\begin{array}{l}\text { All listed financial and } \\
\text { non-financial that was listed on }\end{array}$ & SLS regression. & $\begin{array}{l}\text { Market-to-b } \\
\text { ook value }\end{array}$ \\
\hline & & $\begin{array}{l}\text { Dhaka Stock Exchange. The } \\
\text { sample was based on } 723 \\
\text { companies covering } 8 \text { years } \\
\text { from } 1995 \text { to } 2002 \text {. }\end{array}$ & & \\
\hline
\end{tabular}

Table 1.9: Summary of previous literature that discover there is no relationship between Government ownership and firm

\begin{tabular}{|c|c|c|c|c|}
\hline $\begin{array}{l}\text { Authors } \\
\text { and year }\end{array}$ & Content & Sample & Methods & D.V \\
\hline \multicolumn{5}{|c|}{ In the developing countries } \\
\hline Al-Hussain & Saudi & Nine banks during 2004-2007. & Multiple regression & $\overline{\mathrm{ROA}}$ \\
\hline $\begin{array}{l}\text { \& Johnson } \\
\text { (2009) }\end{array}$ & Arabia & & & \\
\hline
\end{tabular}

The present study attempts to contribute to literature regarding this relationship by proposing the following hypotheses.

H3: There is a positive relationship between the government ownership and firm performance.

\subsection{Foreign Ownership and Firm Performance}

The fourth aspect of superiority of ownership stature is foreign ownership. The present study focuses on foreign shareholders' influence upon corporate performance. Foreign ownership is measured by the ratio of foreign ownership stake to total shareholding as evidenced by $\mathrm{Al}$ Manaseer et al., (2012), Chari et al., (2012) and Uwuigbe and Olusanmi (2012).

The impact of foreign ownership upon bank profitability is associated to various reasons (Al Manaseer et al., 2012); first the capital contributed by foreign investors minimizes the fiscal costs of restructuring of banks (Tang, Zoli \& Klytchnikova, 2000). Second, foreign banks may offer expertise in risk management and a more superior culture of corporate governance, resulting in more efficient banks (Bonin et al., 2005). Third, the presence of foreign banks heightens the competition and urges local banks to cut costs and enhance their efficiency (Claessens \& Fan, 2002). Moreover, if a significant portion of the firm's shares is held by foreign shareholders, it may be an indication that foreign shareholders trust those companies which may result in the higher companies' valuation (NazliAnum, 2010). More importantly, the opening of national economies to foreign trade and investment has great significance on corporate governance practices in the economies (Kim \& Yoon, 2007). The introduction of foreign financial institutions into developing economies is associated to implications in two aspects; first, foreign financial institutions, as they are privately owned and managed, have greater incentives to monitor management to guarantee higher returns on investment compared to public financial institutions. Second, the institutions have superior tools to monitor managers compared to their local counterparts in developing economies (Khanna \& Palepu, 2000; Rapaczynsky, 1996). 
As mentioned time and again in this research, the agency theory has its basis on the owners-managers relationship. The distinction of managers from owners in contemporary firms offers the context of the agency theory function. Contemporary firms are characterized as having widely dispersed ownership, in light of shareholders who have no role in the companies' management. In the same context, Jensen and Meckling (1976) suggested that the firm can be considered as a network of contracts (implicit and explicit) among parties or stakeholders including shareholders, bondholders, employees and even the society. There is a lack of supporting this variable in the previous empirical studies but the current study believes the foreign ownership is a factor that helps to align the interrelationship between owners and manager and at the same time it mitigates the agency cost between the owners and managers.

From resource dependence theory, discussed by Pfeffer (1972) and Pfeffer and Salancik (1978) foreign sources are one outsourcing mechanism which helps to finance the company's capital. Moreover, foreign investors are of the most fundamental factors that help the separation between owners and shareholders and also helps the company to expand control over managers in the decision making process. It also provides established foreign expertise that gives a clear picture about the foreign investments. Finally, the foreign ownership helps to improve performance of firms.

This present study provides many studies around the world that have investigated the relationship between foreign ownership and firm performance in both the developed countries and developing countries. In the end, they found a positive relationship. This current study begins to review the research done in the developed countries. On the contrary, there some authors who have examined the association between foreign and firm performance in both developed countries but they found no relationship (insignificant) between them as provided below.

Table 1.10: Summary of previous studies that there is a positive relationship between foreign ownership and firm performance

\begin{tabular}{|c|c|c|c|c|}
\hline $\begin{array}{l}\text { Authors and } \\
\text { year }\end{array}$ & Country & Sample & Methods & D.V \\
\hline $\begin{array}{l}\text { Chari et al. } \\
(2012)\end{array}$ & U.S. & $\begin{array}{l}\text { The data was selected } \\
\text { during 1980-2006. }\end{array}$ & gression & ROA \\
\hline $\begin{array}{l}\text { Ghahroudi } \\
\text { (2011) }\end{array}$ & Japan & $\begin{array}{l}3500 \text { foreign firms that the } \\
\text { data was obtained by } \\
\text { primary through } 2006 \text {. }\end{array}$ & $\begin{array}{ll}\begin{array}{l}\text { Binary } \\
\text { regression }\end{array} & \text { logistic } \\
\end{array}$ & $\begin{array}{l}\text { Net profit, ROA } \\
\& \text { ROS }\end{array}$ \\
\hline $\begin{array}{l}\text { Sueyoshi et } \\
\text { al. (2010) }\end{array}$ & Japan & $\begin{array}{lr}270 \quad \text { Japanese } & \text { leading } \\
\text { companies } & \text { in } \\
\text { manufacturing } & \text { industry } \\
\text { from } 1999-2006 . & \end{array}$ & OLS & $\begin{array}{l}\text { Operational } \\
\text { performance }\end{array}$ \\
\hline $\begin{array}{l}\text { Filatotchev et } \\
\text { al. }(2007) \\
\end{array}$ & $\begin{array}{l}\text { Poland \& } \\
\text { Hungary } \\
\end{array}$ & $\begin{array}{l}500 \text { largest non-financial } \\
\text { firms in Poland And } 250 \\
\text { largest companies from the } \\
\text { Hungary. }\end{array}$ & $\begin{array}{l}\text { Structural Equation } \\
\text { Modeling (SEM). }\end{array}$ & ROS \& ROA \\
\hline $\begin{array}{l}\text { Xu et al. } \\
(2005)\end{array}$ & China & $\begin{array}{l}40246 \text { industry firms that } \\
\text { were the period } 1997 \text { and } \\
1998 \text {. }\end{array}$ & $\begin{array}{l}\text { Multiple } \\
\text { regressions. The } \\
\text { data was obtained }\end{array}$ & ROA \\
\hline
\end{tabular}


by questionnaire.

\begin{tabular}{|c|c|c|c|c|}
\hline $\begin{array}{l}\text { Ben-Amar \& } \\
\text { Andre }(2006)\end{array}$ & Canada & $\begin{array}{l}327 \text { firms that the period } \\
\text { was during the } 1998 \text { to } \\
2002 \text {. }\end{array}$ & Regressions. & \\
\hline \multicolumn{5}{|c|}{ In the developing countries } \\
\hline $\begin{array}{l}\text { Uwuigbe \& } \\
\text { Olusanmi } \\
(2012)\end{array}$ & Nigeria & $\begin{array}{l}31 \text { firms of all firms in } \\
\text { financial sector during } \\
2006-2010 \text {. }\end{array}$ & $\begin{array}{l}\text { Multivariate } \\
\text { multiple regression. }\end{array}$ & $\mathrm{ROA}$ \\
\hline $\begin{array}{l}\text { Al Manaseer } \\
\text { et al. (2012) }\end{array}$ & Jordan & $\begin{array}{l}15 \text { banks in Jordan over } \\
2007-2009 \text {. }\end{array}$ & $\begin{array}{l}\text { Multiple } \\
\text { Regression }\end{array}$ & $\begin{array}{l}\text { ROE, ROA, PM } \\
\& \text { EPR }\end{array}$ \\
\hline $\begin{array}{l}\text { NazliAnum } \\
(2010)\end{array}$ & Malaysia & 87 non-companies in 2001. & Multiple regression & Tobin-Q \\
\hline $\begin{array}{l}\text { Kim \& Yoon } \\
(2008)\end{array}$ & Korea & $\begin{array}{l}662 \text { firm's observations } \\
\text { from two-year period of } \\
2004-2005 \text {. }\end{array}$ & Regression. & $\begin{array}{l}\text { ROA, COC \& } \\
\text { RET }\end{array}$ \\
\hline $\begin{array}{l}\text { Choi et al. } \\
(2007)\end{array}$ & Korea & $\begin{array}{l}\text { 457companies during } 1999 \\
\text { to } 2002 \text {. }\end{array}$ & Basic regressions, & Tobin-Q \\
\hline $\begin{array}{l}\text { Imam \& } \\
\text { Malik (2007) }\end{array}$ & $\begin{array}{l}\text { Banglade } \\
\text { sh }\end{array}$ & $\begin{array}{l}\text { All non-financial over } \\
2000-2003 \text {. }\end{array}$ & $\begin{array}{l}\text { The multiple } \\
\text { regression }\end{array}$ & Tobin-Q \\
\hline $\begin{array}{l}\text { Douma et al. } \\
\text { 2006) }\end{array}$ & India & $\begin{array}{l}1005 \text { companies that were } \\
\text { listed in Bombay Stock } \\
\text { Exchange through } 1999- \\
2000 \text {. }\end{array}$ & OLS regressions & $\begin{array}{l}\text { ROA } \\
\text { Tobin-Q }\end{array}$ \\
\hline $\begin{array}{l}\text { Filatotchev et } \\
\text { al. (2005) }\end{array}$ & Taiwan & $\begin{array}{l}\text { All firms listed on the } \\
\text { Taiwan Stock Exchange } \\
\text { through } 1999 \text { which was } \\
\text { complied. } \\
\text { sample The final } \\
\text { companies. }\end{array}$ & OLS regressions. & $\begin{array}{l}\text { ROCO, ROA, } \\
\text { EPS \& STIC }\end{array}$ \\
\hline $\begin{array}{l}\text { Dwivedi \& } \\
\text { Jain (2005) }\end{array}$ & India & $\begin{array}{lll}340 \text { large listed } & \text { Indian } \\
\text { firms for the period } \\
1997-2001 \text { spread } & \text { across } \\
24 \text { industry groups. } & \\
\end{array}$ & Regression. & Tobin-Q \\
\hline $\begin{array}{l}\text { Akimova \& } \\
\text { Schwodiauer } \\
(2004) \\
\end{array}$ & Ukraine & $\begin{array}{l}202 \text { medium and large } \\
\text { industrial companies in } \\
\text { Ukraine. The period of } \\
\text { study was during 1998- } \\
2000 \text {. }\end{array}$ & OLS. & $\begin{array}{l}\text { Sales } \\
\text { employee }\end{array}$ \\
\hline
\end{tabular}

Table 1.11: Summary of previous authors that find there is no relationship between foreign ownership and firm performance

\begin{tabular}{llllll}
\hline $\begin{array}{l}\text { Authors } \\
\text { and year }\end{array}$ & Country & Sample & Methods & D.V \\
\cline { 5 - 6 } $\begin{array}{l}\text { Shan } \\
\text { \&McIver }\end{array}$ & China & $\begin{array}{l}540 \text { firm from non-financial } \\
\text { sectors which listed in Hong }\end{array}$ & \begin{tabular}{l} 
Ordinary squares fixed effects \\
\cline { 3 - 5 }
\end{tabular} & &
\end{tabular}




\section{Il Macrothink}

Journal of Sociological Research

ISSN 1948-5468

2013, Vol. 4, No.2

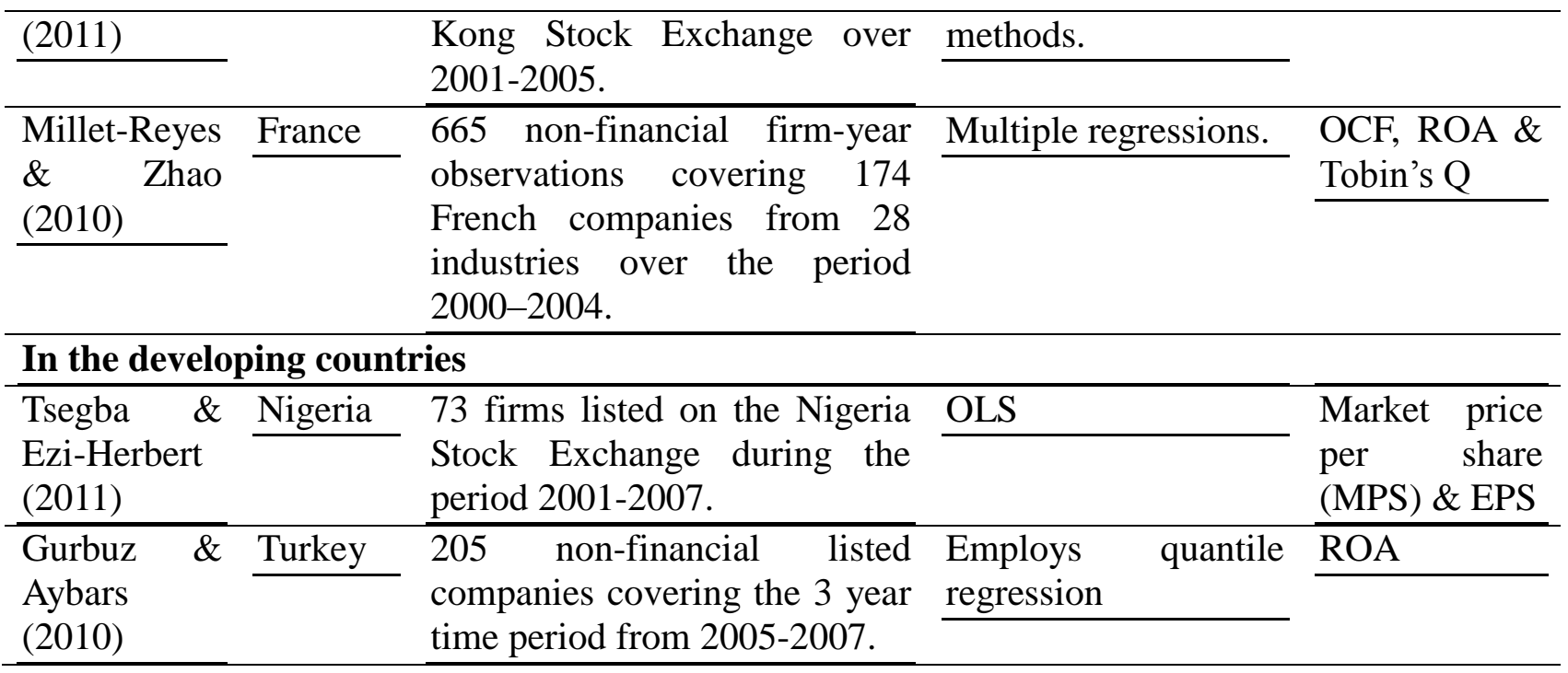

Therefore, this study is planning to contribute to the literature by testing the following hypotheses.

H4: There is a positive relationship between the foreign ownership and firm performance.

\subsection{Institutional Ownership and Firm Performance}

The fifth influence of value of ownership structure is institutional ownership. The institutional ownership is gauged through the ratio of shareholding held by institutions to the total number of shares (Fazlzadeh et al., 2011; Nuryanah \& Islam, 2011).

Institutional investors comprise of organizations pooling significant amounts of money to invest in companies for instance, banks, mutual funds, insurance companies among others. They can command the board to provide shareholders' protection and enhances company governance. With the authority to select directors (for some board seats), they may be able to employ them to oversee the company on their behalf. Lately, directors are more inclined to commit their loyalty to corporate officers as opposed to shareholders who the directors nominally serve. The separation of ownership and control also has a significant role. According to Khanchel (2007), the institutional investors' role in corporate governance system of the company is debatable. However, some are convinced that their role in governance moves the firm from good to great (Khan et al., 2011).

Studies reveal that institutional investors must have some say in the company's corporate governance system. The findings of these studies indicate that for the corporate governance system in the companies to be successful, institutional investors should play a role in the complete process. For instance, Shleifer and Vishny (1986), noted that institutional investors because of their large stock holdings would possess greater incentives for monitoring corporate governance in order to obtain benefits. Additionally, Cremers and Nair (2005) stressed that some institutional investors like pension funds may be more encouraged to monitor compared to others and as such, they are more insistent shareholder activists. In the same context, Moshe (2006) noted that the separation of ownership and control results in an agency problem because managers may run the firm for their benefit and not for the shareholders'; in other words, they may choose maximization of their personal utility and not of shareholder value (Khan et al., 2011). This perspective is similar to agency theory where it recalls the separation between 


\section{Ml Macrothink}

Journal of Sociological Research

ISSN 1948-5468

2013, Vol. 4, No.2

ownership and management to maximize the shareholder's value and give freedom to take decisions. And also resource dependence theory proved that outsource gives a firm a background to deal with expertise and professional person. The outsider has an important incentive to maximize the significance of shareholders.

From both agency theory and resource dependence theory and the above broad discussions, the relationship between institutional ownership and firm performance is supposed to be positive. There are some authors who examined the relationship between institutional ownership and firm performance in the developed countries such as Harjoto and Jo (2008) and Irina and Nadezhda (2009).

Table 1.12: Summary of previous studies that find there is a positive relationship between Institutional ownership and firm performance

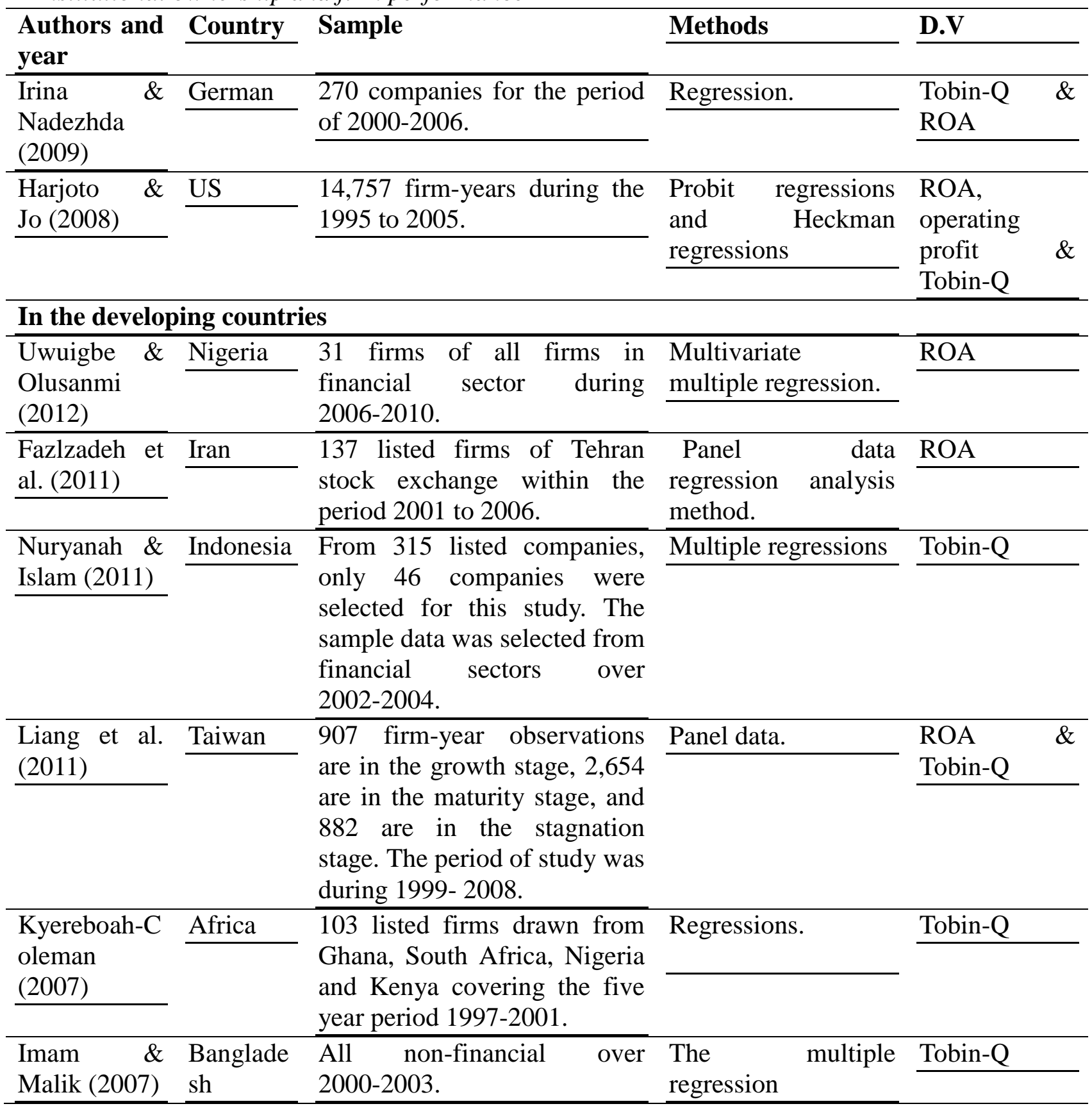




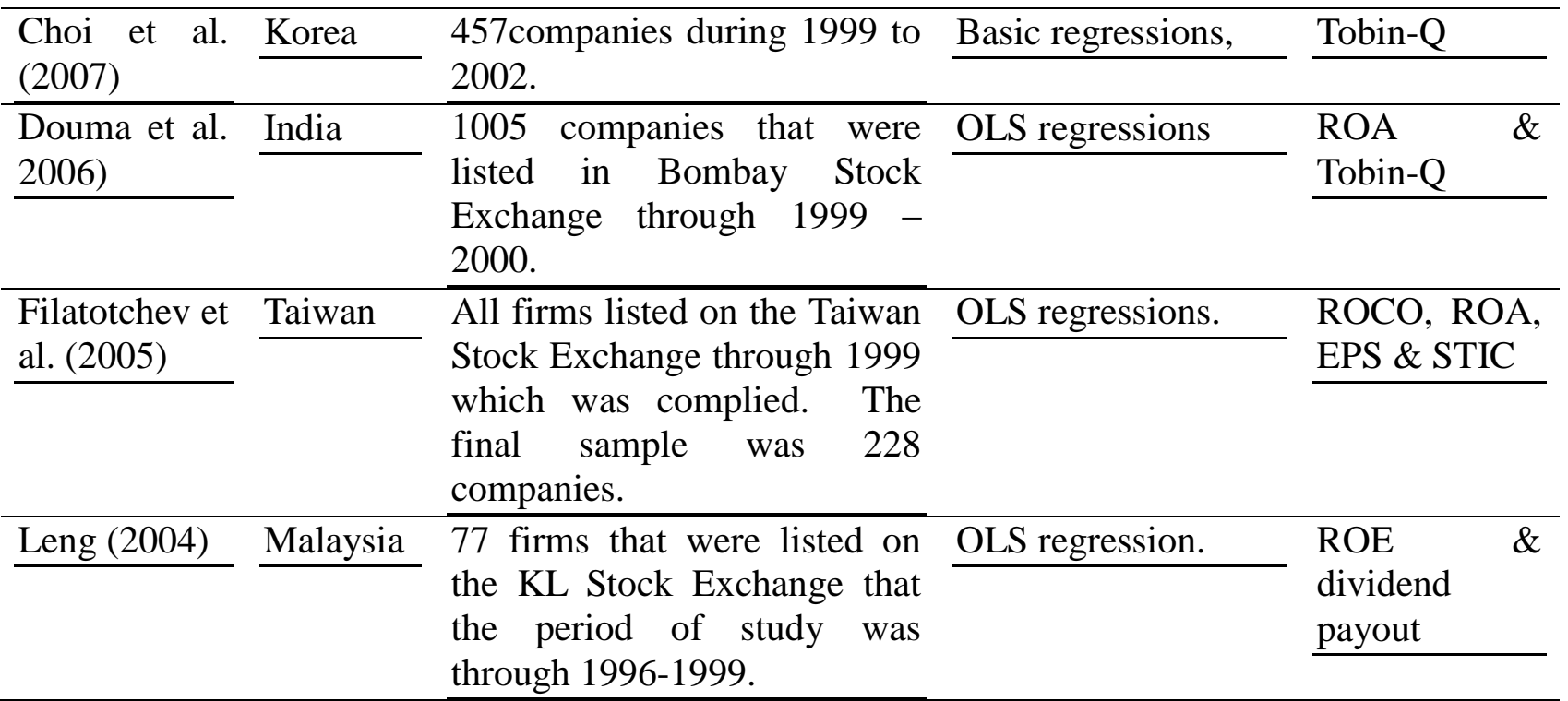

Table 1.13: Summary of previous authors that find there is a negative relationship between Institutional ownership and firm performance

\begin{tabular}{|c|c|c|c|c|}
\hline $\begin{array}{l}\text { Authors } \\
\text { and year }\end{array}$ & Country & Sample & Methods & D.V \\
\hline Mura (2007) & UK & 1100 listed non-financial firms. & $\begin{array}{l}\text { Multivariate } \\
\text { Regression }\end{array}$ & Tobin-Q \\
\hline \multicolumn{5}{|c|}{ In the developing countries } \\
\hline $\begin{array}{l}\text { Mashayekhi } \\
\& \quad \text { Bazazb } \\
(2008)\end{array}$ & Iran & $\begin{array}{l}\text { All companies listed in the Tehran } \\
\text { Stock Exchange (TSE) for the years } \\
\text { 2005-2006. }\end{array}$ & $\begin{array}{l}\text { Multiple } \\
\text { regression } \\
\text { analysis. }\end{array}$ & $\begin{array}{l}\text { ROA, ROE \& } \\
\text { EPS }\end{array}$ \\
\hline $\begin{array}{l}\text { Al Farooque } \\
\text { et al. (2007) }\end{array}$ & $\begin{array}{l}\text { Banglade } \\
\text { sh }\end{array}$ & $\begin{array}{l}\text { All listed financial and } \\
\text { non-financial that was listed on } \\
\text { Dhaka Stock Exchange. The sample } \\
\text { was based on } 723 \text { companies } \\
\text { covering } 8 \text { years from } 1995 \text { to } \\
2002 \text {. }\end{array}$ & SLS regression. & $\begin{array}{l}\text { Market-to-boo } \\
\text { k value }\end{array}$ \\
\hline $\begin{array}{l}\text { Kyereboah- } \\
\text { Coleman } \\
(2007) \\
\end{array}$ & Africa & $\begin{array}{l}103 \text { listed firms drawn from Ghana, } \\
\text { South Africa, Nigeria and Kenya } \\
\text { covering the five year period } \\
1997-2001 .\end{array}$ & Regressions. & ROA \\
\hline
\end{tabular}

Table 1.14: Summary of previous studies that find there is no relationship between Institutional ownership and firm performance

\begin{tabular}{lllll}
\hline $\begin{array}{l}\text { Authors and } \\
\text { year }\end{array}$ & Content & Sample & Methods & D.V \\
\cline { 1 - 3 } $\begin{array}{l}\text { Mizuno } \\
(2010)\end{array}$ & Japan & $\begin{array}{l}\text { The sample was the voting quid } \\
\text { lines of the Pension Fund }\end{array}$ & Tobin-Q \\
Association (PFA) of Japan during \\
2004-2007.
\end{tabular}




\begin{tabular}{|c|c|c|c|c|}
\hline $\begin{array}{l}\text { Herrmann et } \\
\text { al. (2010) }\end{array}$ & US & $\begin{array}{l}350 \text { large manufacturing companies } \\
\text { during } 1991,1994,1997 \text { and } 2000 .\end{array}$ & $\begin{array}{l}\text { Multiple } \\
\text { regression }\end{array}$ & $\begin{array}{l}\text { R\&D } \\
\text { investment }\end{array}$ \\
\hline \multicolumn{5}{|c|}{ In the developing countries } \\
\hline $\begin{array}{l}\text { Chung et al. } \\
\text { (2008) }\end{array}$ & Korea & $\begin{array}{l}377 \text { firms that the period was during } \\
1999 \text { to } 2005 \text {. }\end{array}$ & $\begin{array}{l}\text { Multiple } \\
\text { regressions }\end{array}$ & $\overline{\mathrm{ROA}}$ \\
\hline $\begin{array}{l}\text { Mollah \& } \\
\text { Talukdar } \\
(2007) \\
\end{array}$ & $\begin{array}{l}\text { Banglade } \\
\text { sh }\end{array}$ & $\begin{array}{l}55 \text { firms which were listed on Dhaka } \\
\text { Stock Exchange in Bangladesh. The } \\
\text { data were obtained from } 2002 \text { to } \\
2004 \text {. }\end{array}$ & $\begin{array}{l}\text { OLS } \\
\text { regressions. }\end{array}$ & $\begin{array}{l}\text { ROA, ROE, } \\
\log \text { of market } \\
\& \\
\text { capitalization. }\end{array}$ \\
\hline $\begin{array}{l}\text { Aljifri \& } \\
\text { Moustafa } \\
(2007)\end{array}$ & UAE & 51 firms through 2004 & $\begin{array}{l}\text { Cross-section } \\
\text { al regression }\end{array}$ & Tobin`s Q \\
\hline $\begin{array}{l}\text { Joher \& Ali } \\
(2005)\end{array}$ & Malaysia & $\begin{array}{l}100 \text { firms over } 5 \text { years from } 1997 \text { to } \\
2001 \text {. }\end{array}$ & $\begin{array}{l}\text { Cross-section } \\
\text { al annual }\end{array}$ & ROA \\
\hline $\begin{array}{l}\text { Dwivedi \& } \\
\text { Jain }(2005) \\
\end{array}$ & India & $\begin{array}{l}340 \text { large listed Indian firms for the } \\
\text { period 1997-2001 spread across } 24 \\
\text { industry groups. }\end{array}$ & Regression. & Tobin-Q \\
\hline
\end{tabular}

Thus, the following hypotheses are proposed for empirical examination.

H5: There is a positive relationship between the institutional ownership and firm performance.

\section{Conclusion}

This study is an attempt to provide a comprehensive review of the relationship between ownership structure factors that related to the performance of the company. As the researcher approved that there is a lack of previous studies, in general, in the developed countries and, in particular, in the developing countries to investigate all these factors together with firm performance. So that, this study focused to fill this gap and enrich existing literature review for more improvement in this relation and give a clear recommendations for future studies. As a matter of fact, some authors proved that the ownership structure has a value and positive role to enhance the performance of the firm through offering a high disclosure of information report which, in turn, to lead attractive both local and foreign investors. The ownership is mechnisim that arrange the main relationship between owner and managers as well as, it helps to reduce the agency cost for improvement the firm's performance.

This study is similar to prior study those have many recommendations. Firstly, as important points, this study highlighted the lack of the studies in literature with future recommendations to test this relation empirically in the emerging markets such as gulf countries. Secondly, this study suggested future studies to moderate or meditate some variables that have a significant relationship between ownership structure and firm performance and may lead to more improvement because of the inclusiveness in the previous research results. Thirdly, future studies should integrate ownership structure factors with corporate governance mechanisms, such as board of director's characteristics, audit committee characteristics, risk committee characteristics, executive committee characteristics, compensation committee and others that have an important association with firm performance and will help to enhance it. Finally, this study recommended future studies to test the firm performance through different perspective 
like accounting and marketing measurements because the integration between short term and long term that may help to maximize shareholder wealth.

\section{References}

Abdullah, M. S., Shah, S. Z. A., \& Hassan, A. (2008). Impact of Corporate Governance on Financial Performance of Firms: Evidence from Pakistan. The Business Review, Cambridge, 11, 282-290.

Abdurrouf, M. A. (2011). The relationship between corporate governance and value of the firm in developing countries: Evidence from Bangladesh. The International Journal of Applied Economics and Finance, 5(3), 237-244.

Akimova, I., \& Schwödiauer, G. (2004). Ownership structure, corporate governance, and enterprise performance: Empirical results for Ukraine. International Advances in Economic Research, 10(1), 28-42. doi:10.1007/BF02295575

Al Farooque, O. A., Zijl, T. V., Dunstan, K., \& Karim, A. K. M. W. (2007). Corporate Governance in Bangladesh: Link between Ownership and Financial Performance. Corporate Governance, 15(6), 1453-1469.

Al Manaseer, M. F. A., Al-Hindawi, R. M., Al-Dahiyat, M. A., \& Sartawi, I. I. (2012). The Impact of Corporate Governance on the Performance of Jordanian Banks. European Journal of Scientific Research, 67(3), 349-359.

Al-Hussain, A. H., \& Johnson, R. L. (2009). Relationship between corporate governance efficiency and Saudi Banks' performance. The Business Review, Cambridge ,14(1), 111-117.

Aljifri, K., \& Moustafa, M. (200). The impact of corporate governance mechanisms on the performance of UAE firms: an empirical analysis. Journal of Economic and Administrative Sciences, 23(2), 71-93.

Avantika, T. (2011). Global Recession and Determinants of CEO Compensation: An Empirical Investigation of Listed Indian Firms. Advance in management, 4(12), 27-37.

Azam, M., Usmani, S., \& Abassi, Z. (2011). The Impact of Corporate Governance on Firm's Performance : Evidence from Oil and Gas Sector of Pakistan. Australian journal of basic and applied science, 5(12), 2978-2983.

Bauer, R., Eichholtz, P., \& Kok, N. (2009). Real estate, corporate governance and performance: The Reit Effect. Financial Management, XX(XX), 1-29. doi:10.1111/j.1540-6229.2009.00252.x

Bektas, E., \& Kaymak, T. (2009). Governance mechanisms and ownership in an emerging market : the case of Turkish banks. Journal Emerging Markets Finance and Trade, 45(6), 20-32. doi:10.2753/REE1540-496X450602

Belkhir, M. (2005). Board structure, ownership structure, and firm performance: Evidence from banking. Applied Financial Economics, 19(19), 1581-1593.

Ben-Amar, W., \& Andre, P. (2006). Separation of ownership from control and acquiring firm performance: The case of family ownership in Canada. Journal of Business Finance \& Accounting, 33(3\&4), 517-543. doi:10.1111/j.1468-5957.2006.00613.x

Berle, A., \& Means, G. (1932). The Modern Corporation and Private Property. New York, NY: Macmillan. 
Bhagat, S., \& Bolton, B. (2008). Corporate governance and firm performance. journal pf corporate finance, 14, 257-273. doi:10.1016/j.jcorpfin.2008.03.006

Bhagat, S., \& Bolton, B. (2009). Corporate governance and firm performance: Recent Evidence Sanjai Bhagat, 1-57.

Chahine, S., \& Safieddine, A. (2009). Is corporate governance different for the Lebanese banking system? Journal of Management \& Governance, 15(2), 207-226. doi:10.1007/s10997-009-9096-7

Chang, C. (2009). The Corporate governance characteristics of financially distressed firms : Evidence from Taiwan. The Journal of American Academy of Business, Cambridge, 15(1), 125-133.

Chari, A., Chen, W., \& Dominguez, K. M. E. (2012). Foreign ownership and firm performance: emerging market acquisitions in the United States. IMF Economic Review, 60(1), 1-42. doi:10.1057/imfer.2012.1

Chen, J., Chen, D., \& Chung, H. (2006). Corporate control, corporate governance and firm performance in New Zealand. International Journal of Disclosure and Governance, 3(4), 263-276.

Chiang, H., \& Lin, M. (2011). Examining board composition and firm performance. The International Journal of Business and Finance Research, 5(3), 15-28.

Choi, J. J., Park, S. W., \& Yoo, S. S. (2007). The value of outside directors : evidence from corporate governance reform in Korea. Journal of Financial and Quantitative Analysis, 42(4), 941-963.

Chowdhury, K. (2010). board composition and firm performance : Evidence from Bangladesh. A Sceptical View. $x x x x, 4(3), 103-110$.

Chugh, L. C., Meador, J. W., \& Kumar, A. S. (2011). Corporate governance and firm performance : evidence from India. Journal of Finance and Accounting, 7, 1-10.

Chung, D. S., Kim, B. G., Kim, D. W., \& Choi, S. (2008). Corporate governance and firm perfroamnce: the Korea evidence. Journal of International Business and Economic, 8(2), 46-54.

Claessens, S., \& Fan, J. (2002). Corporate Governance in Asia: A Survey. International Review of Finance, 3(2), 71-103. doi: 10.1111/1468-2443.00034

Cremers, K.J.M., \& Nair, V.B. (2005). Governance mechanisms and equity prices. Journal of the finance, 5(6), 2859-2894.

Dar, L. A., Naseem, M. A., Rehman, R. U., \& Niazi, G. S. (2011). Corporate Governance and Firm Performance a Case Study ofPakistan Oil and Gas Companies Listed in Karachi Stock Exchange. Global Journal of Management and Business Research, 11(8), 1-10.

Demsetz H. (1983). The structure of ownership and the theory of the firm. Journal of Law and Economics, 26, 375-390.

Demsetz H., Lehn K. (1985). The structure of corporate ownership: Causes and consequences, Journal of Political Economy, 93(6), 1155-1177.

Demsetz, H., \& Villalonga, B. (2001). Ownership structure and corporate performance, Journal of Corporate Finance, 7, 209-33.

Dey, A. (2008). Corporate governance and agency conflicts. Journal of Accounting Research, 46(5), 1143-1181. 
Douma, S., George, R., \& Kabir, R. (2006). Foreign and domestic ownership, business groups, and firm performance : Evidence from a Large Emerging Market. Strategic Management Journal, 27(xxx), 637-657. doi:10.1002/smj.535

Dwivedi, N., \& Jain, A. K. (2005). Corporate governance and performance of indian firms: the effect of board size and ownership. Employee Responsibilities and Rights Journal, 17(3), 161-172. doi:10.1007/s10672-005-6939-5

Earle, J. S., Kucsera, C., \& Telegdy, A. (2005). Ownership concentration and corporate performance on the Budapest stock exchange: do too many cooks spoil the goulash? Corporate Governance, 13(2), 254-264. doi:10.1111/j.1467-8683.2005.00420.x

Ehikioya, B. I. (2009). Corporate governance structure and firm performance in developing economies: evidence from Nigeria. Corporate Governance, 9(3), 231-243. doi:10.1108/14720700910964307

Eng, L., \& Mak, Y. (2003). Corporate governance and voluntary disclosure. Journal of Accounting and Public Policy, 22, 325-345.

Fama, E., \& Jensen, M. (1983). Agency problems and residual claims. The Journal of Law and Economics, 26(2), 327-349.

Fama, E.F., \& Jensen, M.C. (1983). Separation of ownership and control. Journal of Law and Economics, 26, 301-325. http://dx.doi.org/10.1086/467037

Fazlzadeh, A., Hendi, A. T., \& Mahboubi, K. (2011). The examination of the effect of ownership structure on firm performance in listed firms of Tehran stock exchange based on the type of the industry. Interactional Journal of Business and Management, 6(3), 249-267.

Filatotchev, I., Isachenkova, N., \& Mickiewicz, T. (2007). Corporate governance, managers' independence, exporting, and performance of firms in transition economies. Emerging Markets Finance and Trade, 43(5), 62-77. doi:10.2753/REE1540-496X430504

Filatotchev, I., Lien, Y.-C., \& Piesse, J. (2005). Corporate governance and performance in publicly listed, family-controlled firms: Evidence from Taiwan. Asia Pacific Journal of Management, 22(3), 257-283. doi:10.1007/s10490-005-3569-2

Florackis, C. (2005). Internal corporate governance mechanisms and corporate performance: evidence for UK firms. Journal of Applied Financial Economics Letters, 1(4), 211-216. doi:10.1080/17446540500143897

Galbreath, J. (2010). Corporate governance practices that address climate change: an exploratory study. Business Strategy and the Environment, 19, 335-350.

Ganguli, S. K., \& Agrawal, S. (2009). Ownership structure and firm performance: An empirical study on listed mid-cap Indian companies. The IUP Journal of Applied Finance, 15(12), 37-52.

Ghahroudi, M. R. (2011). Ownership advantages and firm factors influencing performance of foreign affiliates in Japan. International Journal of Business and Management, 6(11), 119-138. doi:10.5539/ijbm.v6n11p119

Gurbuz, A. O., \& Aybars, A. (2010). The impact of foreign ownership on firm performance, evidence from an emerging market: Turkey. American Journal of Economics and Business Administration, 2(4), 350-359. 
Harjoto, M. A., \& Jo, H. (2008). Board leadership and firm performance. Journal of International Business and Economics, 8(3), 143-155.

Haslindar, I., \& Fazilah, A. (2011). Corporate governance mechanisms and performance of public family-ownership in Malaysia. International Journal of Economics and Finance, 3(1), 105-115.

Hasnah, K. (2009). The impact of corporate governance and board performance on the perfprmance of public listed companies in Malaysia. Ph.D Dissertation, University Sains Malaysia.

Heenetigala, K., \& Armstrong, A. (2011). The impact of corporate governance on firm performance in an unstable economic and political environment: Evidence from Sri Lanka. Conference on financial markets and corporate governance, 13, 1-17.

Hu, H. W., Tam, O. K., \& Tan, M. G. (2010). Internal governance mechanisms and firm performance in China. Asia Pacific Journal of Management, 27, 727-749. doi:10.1007/s10490-009-9135-6

Ibrahim, Q., Rehman, R., \& Raoof, A. (2010). Role of corporate governance in firm performance: A comparative study between Chemical and Pharmaceutical sectors of Pakistan. International Research Journal of Finance and Economics, 50, 7-16.

Imam, M. O., \& Malik, M. (2007). Firm performance and corporate governance through ownership structure : Evidence from Bangladesh Stock Market. International Review of Business Research Papers, 3(4), 88-110.

Irina, I., \& Nadezhda, Z. (2009). The relationship between corporate governance and company performance in concentrated ownership systems: The case of Germany. Journal of Corporate Finance, 4(12), 34-56.

Jackling, B., \& Johl, S. (2009). Board structure and firm performance : Evidence from India's top companies. Corporate Governance: An International Review, 17(4), 492-509. doi:10.1111/j.1467-8683.2009.00760.x

Jandik, T., \& Rennie, C. G. (2008). The Evolution of corporate governance and firm performance in transition economies : The case of sellier and bellot in the Czech Republic. European Financial Management journal, 14(4), 747-791. doi:10.1111/j.1468-036X.2007.00407.x

Jensen, M. \& Meckling, W.H. (1976). Theory of the firm: managerial behavior, agency costs, and ownership structure. Journal of Financial Economics, 3, 305-360. http://dx.doi.org/10.1016/0304-405X(76)90026-X

Jensen, M. (1993). The modern industrial revolution, exit and the failure of internal control systems. Journal of Finance, 48, 831-880. http://dx.doi.org/10.2307/2329018

Jiang, P. (2004). The relationship between ownership structure and firm performance: an empirical analysis over Heilongjiang listed companies. Nature and Science, 2 (4), 87-90.

Joher, H., \& Ali, M. (2005). Corporate governance structure and firm performance: Empirical evidence From Brusa Malaysia, Kuala Lumpur. International Business \& Economics Research Journal, 4(9), 59-66.

Juras, P. E., \& Hinson, Y. L. (2008). Examining the effect of board characteristics on agency costs and selected performance measures in banks. Academy of Banking Studies Journal, 7(2), 87-108. 
Kang, S., \& Kim, Y. (2011). Does earnings management amplify the association between corporate governance and firm performance? Evidence from Korea. International Business and Economies Research Journal, 10(2), 53-67.

Kapopoulos, P., \& Lazaretou, S. (2007). Corporate ownership structure and firm performance : evidence from Greek firms. Corporate Governance, 15(2), 144-159.

Karaca, S. S., \& Ekşi, I. H. (2012). Corporate governance as a driver of organizational efficiency in courier service firms : Empirical findings from Nigeria. Interdisciplinary Journal of Research In Business, 1(11), 26-38.

Karaca, S. S., \& Ekşi, İ. H. (2012). The relationship between ownership structure and firm performance: An empirical analysis over İstanbul Stock Exchange (ISE) listed companies. International Business Research, 5(1), 172-181.

Khan, K., Nemati, A. R., \& Iftikhar, M. (2011). Impact of corporate governance on firm performance evidence from the Tobacco industry of Pakistan. International Research Journal of Finance and Economics, 61, 7-14.

Khan, M., \& Javid, A. (2011). Determinants of board effectiveness: Logit model ferheen kayani. Interdisciplinary Journal of Contemporary Research in Business, 3(2).1970-1981.

Khanna, T., \& Palepu, K. (2000). Is group affiliation profitable in emerging markets? An analysis of diversified Indian business groups. Journal of Finance, 55(2), 867-91.

Kim, H. J., \& Yoon, S. S. (2007). Corporate governance and firm performance in Korea. Malaysian Accounting Review, 6(2), 1-18.

Kota, H.M., \& Tomar, C. (2010). Corporate governance practices of Indian firms. Journal of Management and Organization, 16, 266-279. http://dx.doi.org/10.5172/jmo.16.2.266

Kyereboah-Colema, A. (2007). Corporate governance and firm performance in Africa: A dynamic panel data analysis. Studies in Economics and Econometrics, 32(2), 1-24.

Kyereboah-Coleman, A., \& Biekpe, N. (2006). The link between corporate governance and performance of the non-traditional export sector: evidence from Ghana. Corporate Governance Journal, 6(5), 609-623. doi:10.1108/14720700610706090

La Port, R., Lopez-De-Silanes, F., \& Shleifer, A. (1999). Corporate ownership around the world. The Journal of Finance, 54 (2), 471-517.

La Porta, R., Lopez-de-Silanes, F., Shleifer , A., Vishny, R.W. (2000). Investor protection and corporate governance. Journal of Financial Economics, 58, 3-29.

Lemmon, M., \& Lins, K. (2001). Ownership structure, corporate governance, and firm Value: Evidence from the East Asian financial crisis. The Journal of Finance, XVII(4).1445-1468.

Leng, A. C. A. (2004). The impact of corporate governance practices on firms' financial performance: Evidence from Malaysia companies. ASEAN Economic Bulletin, 21(3), $308-318$.

Leung, S., \& Horwitz, B. (2010). Corporate governance and firm value during a financial crisis. Review of Quantitative Finance and Accounting, (34), 459-481. doi:10.1007/s11156-009-0141-z 


\section{Macrothink}

Journal of Sociological Research

ISSN 1948-5468

2013, Vol. 4, No.2

Liang, C.-J., Lin, Y.-L., \& Huang, T.-T. (2011). Does endogenously determined ownership matter on performance? Dynamic evidence from the emerging Taiwan market. Emerging Markets Finance and Trade, 47(6), 120-133. doi:10.2753/REE1540-496X470607

Lin, C. (2011). An examination of board and firm performance: evidence from Taiwan. The International Journal of Business and Finance Research, 5(4), 17-35.

Mak, T., \& Li, Y. (2001). Determinants of corporate ownership and board structure: Evidence from Singapore. Journal of Corporate Finance, 1(1), 236-256.

Mandacı, P. E., \& Gumus, G. K. (2010). Ownership concentration, managerial ownership and firm performance: Evidence from Turkey. SEE journal, 57-66. doi:10.2478/v10033-010-0005-4

Mashayekhi, B., \& Bazazb, M. S. (2008). Corporate governance and firm performance in Iran. Journal of Contemporary Accounting \& Economics, 4(2), 156-172. doi:10.1016/S1815-5669(10)70033-3

Millet-Reyes, B., \& Zhao, R. (2010). A comparison between one-tier and two-tier board structures in France. Journal of International Financial Management and Accounting, 21(3), 279-310.

Mohd, A.M.N. (2011). The effect of implementation of Malaysia code of corporate goverance (MCCG) 2007 on corporate governance attributes and financial performance. Ph.D DPA Dissertation, University Utara Malaysia.

MoIlah, A. S., \& Talukdar, M. B. U. (2007). Ownership structure, corporate governance, and firm's performance in emerging markets: Evidence from Bangladesh. The International Journal of Finance, 19(1), 4315-4333.

Morck, R., Shleifer, A., \& Vishny, R. (1988). Management ownership and market valuation: An empirical analysis. J. Fin. Econ., 20, 293-315.

Moshe, P. (2006). The role of institutional investors in the corporate governance. Working Papers in Law and Economics. 1-71.

Mura, R. (2007). Firm performance: Do non-executive directors have minds of their own? Evidence from UK panel data. Financial Management, 81 -112.

Muravyev, A., Talavera, O., Bilyk, O., \& Grechaniuk, B. (2010). Is corporate governance effective in Ukraine? Eastern European Economics, 48(2), 5-24. doi:10.2753/EEE0012-8775480201

Najjar, N. (2012). The impact of corporate governance on the insurance firm's performance in Bahrain. International Journal of Learning and Development,2(2), 1-17.

NazliAnum, M. G. (2010). Ownership structure, corporate governance and corporate performance in Malaysia. International Journal of Commerce and Management, 20(2), 109-119.

NurulAfzan, N., \& Rashidah, A. (2011). Government ownership and performance of Malaysian government-linked companies. International Research Journal of Finance and Economics, (61), 42-56.

Nuryanah, S., \& Islam, S. M. N. (2011). Corporate governance and performance : Evidence from an emerging market. Malaysian Accounting Review, 10(1), 17-42 
O`Connell, V., \& Cramer, N. (2010). The relationship between firm performance and board characteristics in Ireland. European Management Journal, (28), 387-399. doi:10.1016/j.emj.2009.11.002

Obiyo, O. C., \& Lenee, L. T. (2011). Corporate governance and firm performance in Nigeria. IJEMR, 1(4), 1-12.

Pfeffer, J. (1972). Size, composition, and function of hospital boards of directors. Administrative Science Quarterly, 18(2), 349-364.

Pfeffer, J. (1987). A resource dependence perspective on interorganizational relations. In M. S. Mizruchi, \& M. Schwartz (Eds.), Intercorporate relations: The structural analysis of business: 22-55. Cambridge, UK: Cambridge University Press.

Pfeffer, J., \& Slanick, G.R. (1979). The external control of organizations: a resource dependence perspective. Contemporary Sociology, 8 (4), 612-13.

Rachdi, H., \& Ameur, I. G. (2011). Board characteristics, performance and risk taking behaviour in Tunisian banks. International Journal of Business and Management, 6(6), 88-98. doi:10.5539/ijbm.v6n6p88

Rapaczynsky, A. (1996). The roles of the state and markets in establishing property rights. Journal of Economic Perspectives, 10, 87-103.

Rhoades, M., Juleff, L., \& Paton, C. (2001). Corporate governance in the financial services sector. International Journal of Business, 7(5), 623-634.

Roszaini, H., \& Mohammad, H. (2006). Corporate governance structure and performance of Malaysian listed companies. Journal of Business Finance \& Accounting, 33(7) \& (8), 1034-1062.

Sa'nchez-Marı'n, G., Baixauli-Soler, J. S., \& Lucas-Pe'rez, M. E. (2010). When much is not better? Top management compensation, board structure, and performance in Spanish firms. The International Journal of Human Resource Management, 21(15), 2778-2797. doi:10.1080/09585192.2010.528660

Sánchez-Ballesta, J. P., \& García-Meca, E. (2007). A meta-analytic vision of the effect of ownership structure on firm performance. Corporate Governance, 15(5), 879-894.

Sanda, A., Mikailu, A. S., \& Garba, T. (2005). Corporate governance mechanisms and firm financial performance in Nigeria. $x x x, x x x(\mathrm{xxx}), 1-47$.

Shahab-u-Din., \& Javid, A. (2011). Impact of managerial ownership on financial policies and the firm's performance: Evidence Pakistani manufacturing firms. International Research Journal of Finance and Economics, (81).13-29.

Shan, Y. G., \& McIver, R. P. (2011). Corporate governance mechanisms and financial performance in China: panel data evidence on listed non-financial companies. Asia Pacific Business Review, 17(3), 301-324. doi:10.1080/13602380903522325

Shao, G. (2010). The effects of board structure on media companies' performance: A stakeholder perspective. Journal of Media Business Studies, 7(3), 1-16.

Sheu, H., \& Yang, C. (2005). Insider ownership structure and firm performance: A productivity perspective study in Taiwan's electronics industry. Journal of Corporate Governance, 13(2), 326-337.

Shleifer, A., \& Vishny, R. W. (1986). Large shareholders and corporate control. Journal of Political Economy, 94(3), 461-488. 
Shleifer, A., \& Vishny, R.W. (1997). A survey of corporate governance. Journal of Finance, 52(2), 737-783. http://dx.doi.org/10.2307/2329497

Shleifer, A., \& Vishny. (1988), Value maximization and the acquisition process. Journal of Economic Perspective, 2(1), 7-20.

Siala, F., Adjaoud, F., \& Mamoghli, C. (2009). The combined effect of external auditor reputation and internal corporate governance on performance. Journal of Academy of Business and Economics, 9(2), 16-29.

Sing, T. F., \& Sirmans, C. F. (2008). Does real estate ownership matter in corporate governance? Journal of property research, 25(1), 23-43. doi:10.1080/09599910802397065

Singh, D. A., \& Gaur, A. S. (2009). Business group affiliation , firm governance, and firm performance : Evidence from China and India. Corporate Governance: An International Review, 17(4), 411-425. doi:10.1111/j.1467-8683.2009.00750.x

Stanwick, P. A., \& Stanwick, S. (2010). The relationship between corporate governance and financial performance: An empirical study of Canadian firms. The Business Review, $16(2), 35-42$.

Sueyoshi, T., Goto, M., \& Omi, Y. (2010). Corporate governance and firm performance: Evidence from Japanese manufacturing industries after the lost decade. European Journal of Operational Research, 203(3), 724-736. doi:10.1016/j.ejor.2009.09.021

Switzer, L. N., \& Tang, M. (2009). The impact of corporate governance on the performance of U.S. Small-Cap Firms. International Journal of Business, 14(4), 341-356.

Tang, H., Zoli, E., \& Klytchnikova I., (2000). Banking crises in transition economies. Fiscal costs and related issues. World bank policy research working paper no. 2484.

Tsegba, I. N., \& Ezi-herbert, W. (2011). The relationship between ownership structure and firm performance : Evidence from Nigerian. African Journal of Accounting, Economics, Finance and Banking Research, 7(7), 51-63.

Uadiale, O. M. (2010). The impact of board structure on corporate financial performance in Nigeria. International Journal of Business and Management, 5(10), 155-166.

Uwuigbe, U., \& Olusanmi, O. (2012). An empirical examination of the relationship between ownership structure and the performance of firms in Nigeria. International Business Research, 5(1), 208-216. doi:10.5539/ibr.v5n1p208

Valenti, M. A., Luce, R., \& Mayfield, C. (2011). The effects of firm performance on corporate governance. Management Research Review, 34(3), $266 \quad-\quad 283$. doi:10.1108/01409171111116295

Wahla, K. U. R., Shah, S. Z. A., \& Hussain, Z. (2012). Impact of ownership structure on firm performance evidence from non-financial listed companies at Karachi stock exchange. International Research Journal of Finance and Economics, (84), 6-13.

Wang, Y., \& Oliver, J. (2009). Board composition and firm performance variance : Australian evidence. Accounting Research Journal, 22(2), 196-212. doi:10.1108/10309610910987510

Weir, C., Laing, D., \& McKnight, P. (2002). Internal and external governance mechanisms: Their impact on the performance of large UK public companies. Journal of Business Finance \& Accounting, 29(5\&6), 579-611. 
Xu, L. C., Zhu, T., \& Lin, Y. (2005). Politician control, agency problems and ownership reform : Evidence from China. Economics of Transition, 13(1), 1-24.

Yasser, Q. R., Entebang, H., \& Mansor, S. A. (2011). Corporate governance and firm performance in Pakistan: The case of Karachi Stock Exchange (KSE). Journal of Economic And International Finance, 3(8), 482-491.

Zubaidah, Z. A., Nurmala, M. K., \& Kamaruzaman, J. (2009). Board structure and corporate performance in Malaysia. International Journal of Economic and Finance, 1(1), $150-164$. 